\title{
A ATIVIdAde de obSERVAÇÃo NAS PRÁtiCAS DE ORIENTAÇÃo A PROFESSORES: UMA PERSPECTIVA CRÍTICA ${ }^{1}$
}

\author{
(The activity of observation in teacher development practices: \\ a critical perspective)
}

\author{
Maria Otilia Guimarães NININ \\ (COGEAE-PUC-SP / UNIP-SP)
}

\begin{abstract}
REsUMO: Este artigo tem por objetivo discutir como o processo de observação em sala de aula é entendido por docentes observadores. Pauta-se na pesquisa crítica, fundamentandose teoricamente na Teoria da Atividade (Engeström, 1987, 1999a, 1999b), nos autores que discutem linguagem e reflexão crítica (Magalhães, 2000; Liberali, 1994) e no papel do discurso na construção dos significados (Halliday, 1985; Halliday E Hasan, 1989). O artigo apresenta uma introdução, justificando a importância do procedimento de observação no desenvolvimento de professores, e está organizado em três partes: fundamentação teórica sobre o processo de observação; metodologia, onde descrevo procedimentos de registro da observação; e discussão dos registros coletados, à luz da lingüística sistêmico-funcional. Do ponto de vista do observador, os resultados mostramnos que a observação pode ser instrumento de desenvolvimento apenas para o participante observado. O poder da observação como instrumento de medida e avaliação mostra-se fortemente marcado pelas escolhas lexicais dos participantes.

PALAVRAS-CHAVE: observação; reflexão; instrumento; reflexão crítica.
\end{abstract}

\footnotetext{
1. Neste artigo, o conceito de crítica está apoiado nos autores Mc Laren e Giroux (1997/2000, p.42), Mc Laren (1977/1997, p.200), dentre outros. Para esses autores, a natureza dialética da teoria crítica permite ao pesquisador em educação ver a escola não simplesmente como uma arena de doutrinação ou socialização ou um local de instrução, mas também como um terreno cultural que confere poder ao aprendiz e promove a autotransformação. Para ambos, ainda, a pedagogia crítica está preocupada com a forma pela qual conhecimento produz tanto o significado como a influência, como ele vem a ser uma moeda cultural que ressoa e estende os interesses que tanto os professores como os estudantes legitimam dentro do contexto da sala de aula.
}

D.E.L.T.A., 25:2, 2009 (347-400) 
ABSTRACT: This paper aims to discuss how the process of observation in classes is understood by observing teachers. It is based on critical research and the theoretical frame refers to the Activity Theory (Engeström, 1987, 1999a, 1999b), in authors that discuss language and critical reflection (Magalhães, 2000; Liberali, 1994), and the role of speech in the construction of meanings (Halliday, 1985; Halliday $\&$ Hasan, 1989). The paper presents an introduction in which I justify why observation is an important procedure on development of teachers and it is organized in three sections: the theoretical frame about the process of observation; the methodology that describes procedures of collected data; and the discussion of data, supported by systemic functional linguistics. According the observer, the results show us that the observation can be instrument of development only for the observed participant. The power of the observation as instrument of measure and evaluation is strongly marked by the lexical choices of the participants. KEY-WORDS: observation; reflection; instrument; critical reflection.

\section{Introdução}

Muitas são as áreas de trabalho hoje em dia, que apóiam seus procedimentos de treinamento a profissionais em processos de observação do trabalho de outros mais experientes. Haja vista, por exemplo, o que vem ocorrendo na área empresarial: o impulso dado ao trabalho de estagiários que, primeiramente, observam o trabalho de funcionários mais experientes e em seguida, passam a trabalhar sob a observação desses mesmos funcionários experientes. Com que propósito? Na verdade, quando recorrem a esse tipo de estratégia, esperam aprender uns com os outros e preparar-se de forma mais adequada para o ambiente de trabalho.

Nas tarefas educacionais, embora ainda pautadas no trabalho solitário dos professores, existe, hoje em dia, um grande desejo de que uns aprendam com os outros e pratiquem o exercício de discutir sobre o que fazem. Pesquisadores, preocupados com o desenvolvimento dos educadores em geral, e considerando o processo de aprendizagem destes, discutem veementemente como aprendem, como constroem conhecimento e como ensinam. Exemplificando, Clot (2006, p.28) afirma que

pode-se levantar a hipótese de que a estrutura da atividade do trabalbo do professor é a mesma estrutura das atividades dos alunos. No fundo, os conflitos nas atividades do ofício de professor são conflitos de atividades que obedecem ao mesmo funcionamento que o das atividades dos alunos. Há, pois, uma estrutura comum da atividade. Em relação à formação dos professores, 
se nós lhes dermos a possibilidade, por técnicas adequadas, de se reapropriarem de suas atividades em seus conflitos, isso lhes poderia dar meios para pensar os conflitos de seus alunos. Em suma, seria um trabalho de auto-análise de suas atividades para melhor identificar os conflitos nos quais se encontram.

É comum coordenadores pedagógicos conversarem e explicitarem expectativas em relação às aulas deste ou daquele professor, sem muito bem conhecerem o que se passa em sua sala de aula. Esperam que esses professores trabalhem da forma como a escola deseja, fundamentando suas ações nas orientações didático-pedagógicas adotadas pela escola, mas, na verdade, não têm certeza das ações dos professores.

Todo esse quadro está diretamente relacionado ao discurso desenvolvido por professores durante suas aulas, objeto de estudo de muitos pesquisadores da atualidade. Nessa direção, encontram-se diversas dissertações e teses baseadas em pesquisa-ação, que têm como foco as ações do próprio pesquisador em sua sala de aula, como por exemplo: Melo (2002), Santos (2002), Dalacorte (2003), Hirano (2003), Lucioli (2003), Zygmantas (2004), Szundy (2005).

Procedimentos como quadros de resultados avaliativos dos alunos, hoje já pouco utilizados em escolas, tinham por objetivo mostrar ao professor irregularidades em sua forma de ensinar, mas sabemos que diagnósticos baseados apenas em notas não retratam com nitidez as relações de sala de aula e nem sempre revelam o perfil do professor e de seus alunos. Há muito mais do que somente notas interferindo na relação professor-aluno e na complexa dinâmica que envolve uma aula.

Procurando compreender cada um dos aspectos relacionados às ações do professor em sala de aula, e esperando que aqueles se proponham a refletir sobre sua prática, suas experiências, suas frustrações e expectativas, em busca de desenvolver-se profissionalmente, pesquisadores lançam mão de recursos como a observação do fazer docente e discutem os procedimentos e estratégias necessárias à ação de observar, considerando a complexidade existente em relação à construção do saber do professor, às contradições entre conhecimento e competência, e à capacidade de agir no mundo.

Nessa perspectiva, este artigo tem como objetivo discutir como o processo de observação em sala de aula, é entendido pelos docentes observadores, sejam eles professores ou coordenadores pedagógicos que procuram 
seus pares para conversar. Procura responder à pergunta: Como são produzidos os sentidos ${ }^{2}$ das ações do professor observado, do ponto de vista do observador? Importante ressaltar que o propósito do artigo não é discutir a observação do ponto de vista da interação entre observador e observado, mas apenas a ação de observar. Dessa forma, têm papel relevante os enunciados produzidos pelo observador. Espero com isso que, ao estabelecer metas e critérios para a produção de um texto de observação da ação docente, observador e observado possam utilizá-lo para um trabalho posterior, em discussões orientadas em seus grupos de trabalho.

A fim de responder à questão proposta e às demais indagações que o tema suscita, este artigo organiza-se em três partes. Na primeira, Perspectivas teóricas, apresento referências teóricas que sustentam a discussão sobre observação da ação docente e sua relação com a reflexão crítica, apoiandome na Teoria da Atividade. Na segunda parte, Mapeando a observação, apresento: orientação metodológica utilizada para a geração dos registros, procedimentos de observação adotados e procedimentos para a análise dos registros. Na terceira parte, Desvendando a observação, procuro analisar, do ponto de vista discursivo, diferentes formas de observação coletadas para este trabalho e sentidos construídos pelo observador no decorrer do processo de observação. Finalizo o artigo apresentando impressões pessoais sobre esse processo e orientações a outros pesquisadores para que avancem na elaboração de novas metodologias sobre observação em sala de aula.

2. Os termos "sentido" e "significado" são utilizados no decorrer deste trabalho com base na concepção vygotskyana, como discutido por Luria (1986/2001), que enfatiza a genericidade do significado, afirmando que "significado é um sistema estável de generalizações, que se pode encontrar em cada palavra, igualmente para todas as pessoas. [...] Por sentido entendemos o significado individual da palavra.Vemos, então, que a mesma palavra possui um significado, formado objetivamente ao longo da história e que, em forma potencial, conserva-se para todas as pessoas, refletindo as coisas com diferente profundidade e amplitude. Porém, junto com o significado, cada palavra tem um sentido [...] ligado à situação dada e com as vivências afetivas do sujeito". Assim, o significado de uma ação diz respeito, portanto, ao conteúdo da ação em si, que é genérico e historicamente situado. O sentido diz respeito às razões e aos motivos que levam o ser humano a agir da forma como age, e é dado a conhecer por meio da atividade orientada a um objeto, da qual esse ser humano participa conscientemente. 


\section{Perspectivas teóricas}

O processo de observação da ação docente nas escolas é analisado neste artigo com base na reflexão crítica, ancorado na Teoria da Atividade, sendo, portanto, considerado como uma atividade de um sistema maior que envolve todos os procedimentos educacionais que ocorrem na escola. Nessa perspectiva, a atividade de observação será discutida a partir de três importantes pilares: observação em si, conflito e negociação. Para organizarmos e sistematizarmos o processo de observação é fundamental que tenhamos a compreensão dos aspectos citados, uma vez que a harmonia entre eles é que pode propiciar um ambiente favorável à construção do conhecimento numa visão crítica que, como apontada por Giroux (1999), não pode se basear em comportamentos e posturas individuais ou em técnicas que reproduzem valores sócio-culturais dominadores ou silenciadores dos conflitos.

Assim, esta seção procura apresentar os pilares citados e como se interrelacionam no processo de observação em sala de aula. Ao final da seção, a partir dos aspectos teóricos discutidos, proponho um quadro orientador que busca resposta às perguntas: $\mathrm{O}$ que é observação? Como fazer observação? Por que fazer observação? Para que fazer observação? A quem observar? Quando observar?

Iniciando, apresento as razões por meio das quais opto por ancorar este trabalho na Teoria da Atividade.

\subsection{Situando a observação na Teoria da Atividade}

Observar tarefas docentes não é um procedimento comum para a maioria dos professores e escolas. Podemos dizer que isso vem conquistando espaço nas discussões pedagógicas (Magalhães, 1992, 1996; Richards e Lockhart, 1994; Celani e Magalhães, 2001), mas ainda é visto pela grande maioria dos professores como uma novidade imposta pelas novas tendências pedagógicas adotadas. Considero este o primeiro dos indícios que me levaram a procurar, na Teoria da Atividade, o suporte para as discussões propostas neste artigo. Apresento, a seguir, uma síntese dos principais conceitos que orientam os estudos da Teoria da Atividade, para então justificar minha escolha por essa teoria como suporte às discussões sobre observação. 
A Teoria da Atividade tem suas raízes na psicologia histórico-cultural, tendo como representante primeiro, o psicólogo russo Lev S. Vygotsky. Seus estudos iniciais sobre atividade desencadearam uma série de outros (Leontiev, 1978; Luria, 1986/1998, 1986/2001; Cole \& Engeström, 1993; Engeström, 1999a, 2001), e inúmeras teses vêm se fundamentando nos conceitos discutidos por esses autores, quando se trata de entender o fazer humano. Essa teoria tem sido elaborada com um propósito: ajudar-nos a entender as transformações sociais atuais, numa perspectiva tal que, dialeticamente, seja possível estabelecer um elo entre estrutura social e individual (Engeström, 1999b), dando maior consideração às ações praticadas pelo indivíduo.

Pelo fato da Teoria da Atividade ter como foco a natureza complexa, situada e distribuída de um fazer humano em andamento, ela nos oferece uma possibilidade de olhar para o trabalho que está sendo realizado pelos indivíduos de maneira consistente com nosso compromisso epistemológico em relação à práxis. Ela também sustenta a idéia (Bedny, 2000) de que planos, motivos, métodos de performance e comportamento orientado por metas podem ser formulados consciente ou inconscientemente, mas a meta de uma atividade é sempre consciente. Nesse contexto, a consciência do ser humano, embora determinada pela matéria e historicamente situada, não é passiva, mas lhe possibilita agir sobre o mundo e modificá-lo (Aranha \& Martins, 1993/1997). A consciência tem, portanto, um duplo papel: é determinada pela matéria, por tudo o que há no mundo, mas é determinante das transformações da própria matéria e do mundo.

Nesse sentido, seguem os estudos de Vygotsky (1934/2000), para quem atividade socialmente significativa poderia servir para explicar consciência bumana e ainda ser uma força geradora dessa consciência. Por volta de 1930, Alexei Leontiev apresenta sua versão para a teoria, apontando, como elemento fundamental, as ações práticas, e delegando a um segundo plano os signos que exerciam papel de mediadores da atividade humana. Ou seja, o foco da teoria da atividade deixa de ser psicológico: passa da busca do desenvolvimento da consciência para a compreensão de ações de ordem prática executadas pelos seres humanos. Essas ações podem ser entendidas como cadeias de operações, rotinas bem definidas e planejadas conscientemente, com metas imediatas. Podem pertencer a atividades diferentes. São processos subordinados a uma finalidade consciente relacionada ao resultado final pretendido para a atividade. Já as operações são os modos de desempenhar uma ação. Referem-se ao aspecto prático da realização das ações. 
Hoje, porém, a Teoria da Atividade transcende sua origem. Segundo Engeström (1999a), pode ser apresentada em três gerações, considerandose fundamentalmente seu foco: o desenvolvimento da consciência do ser humano em situações de atividade social prática, preocupando-se em explicar como impactos psicológicos de uma atividade interferem nela própria e podem ser também geradores de consciência humana. Nessa perspectiva, considera-se uma rede de elementos contextuais, sendo que o primeiro deles, o sujeito da atividade, refere-se à pessoa ou ao grupo de pessoas engajadas na atividade e cujo ponto de vista é tomado na análise da atividade. No contexto deste trabalho, podemos considerar o professor observador e o professor observado. A comunidade pode ser entendida como o grupo de pessoas que compartilham o objeto da atividade com o sujeito. Não é possível afirmar que todos os membros dessa comunidade compartilham o objeto da atividade, mas isso é desejado, ou seja, na medida em que mais e mais sujeitos compartilham o objeto da atividade, maior é a probabilidade da atividade ser impulsionada em direção ao resultado desejado. O objeto da atividade é o alvo da atividade, em relação ao qual os sujeitos agem e sentem uma necessidade. Pode ser entendido como "propiciar contextos na escola favoráveis à aprendizagem de docentes", que os conduz ao possível resultado "desenvolvimento das habilidades de pensamento crítico de alunos e professores". O objeto é algo que está em transformação enquanto a atividade ocorre. Artefatos são todos os meios que os sujeitos têm à sua disposição para influenciar o objeto da atividade e transformá-lo em resultado. Podem ser concretos ou abstratos como, por exemplo: linguagem, sinais e símbolos, procedimentos, máquinas, métodos, leis, formas de organização do trabalho. Exercem o papel de mediadores entre os elementos de uma atividade. São criados e transformados durante a atividade, carregam com eles uma cultura que é formada por sua própria história de desenvolvimento. Seu uso é uma autodeterminação do ser humano. No contexto deste trabalho podemos considerar as teorias pedagógicas, os materiais didáticos, o próprio texto produzido pelos professores observado e observador. As regras, numa atividade, são as leis, normas, padrões, políticas, estratégias, assuntos éticos no plano social e da comunidade, valores e crenças usados no desenvolvimento da atividade, que servem para regular as ações e interações entre os sujeitos envolvidos. Podem ser implícitas ou explícitas. A divisão de trabalho é entendida como a organização explícita e implícita de uma comunidade. Refere-se tanto à forma como as tarefas são divididas horizontalmente entre os membros da comunidade quanto verticalmente em relação ao poder e status dos participantes. 
Considerando-se que atuam em um sistema de atividade diversos sujeitos movidos por diferentes perspectivas, a definição dos objetos é fortemente marcada por relações de poder que emergem na multiplicidade de vozes, ou seja, na presença intensa de diferentes pontos de vista, sustentados por tradições histórico-culturais, por interesses da comunidade e pelo conhecimento que cada sujeito envolvido tem do que se deseja construir.

Assim, observação pode ser entendida como uma atividade em que o sujeito observador e o sujeito observado constroem significados com base em suas histórias e nos processos culturalmente construídos, relacionados ao fazer docente. Tal atividade não se caracteriza, portanto, pela estabilidade nem tampouco por momentos de harmonia e tranqüilidade e sim, pela forte presença de conflitos e contradições que podem ser justificados se pensarmos que os envolvidos têm histórias diferentes e as construíram com base em diferentes visões de mundo e relações interpessoais. Os sujeitos, num sistema de atividade, tanto são responsáveis por estabelecerem momentos de conflito quanto por lidar com esses conflitos, buscando fazer deles impulsos para aprendizagem e desenvolvimento.

Engeström (1999a) enfatiza a importância das contradições e conflitos no desenrolar de uma atividade, argumentando que debruçar-se sobre eles de forma reflexiva e crítica é o fator que levará ao desenvolvimento e às transformações no âmbito social, pois os envolvidos estarão negociando pontos de vista e buscando compreensão não no nível individual mas sim, da coletividade.

Considerando essa perspectiva, este estudo procura articular os conceitos de observação, conflito e negociação aos elementos que fundamentam a Teoria da Atividade. Na seção a seguir discuto observação.

\subsection{Nas tessituras da observação}

O significado dicionarizado de observação / observar, conforme Ferreira (1993, p.388), oferece-nos: "observar - (1) examinar miudamente; estudar. (2) espiar. (3) cumprir ou respeitar as prescrições ou preceitos de. (4) advertir, admoestar. (5) examinar atentamente a(s) pessoa(s) e/ou o ambiente que a(s) cerca. (6) vigiar as próprias ações". Considerando-se a heterogeneidade no campo discursivo, é possível relacionarmos a palavra observação a outros significados, tais como: anotação, análise, aparte, apon- 
tamento, nota, comentário, ressalva, restrição, explicação, percepção, lembrete, explanação, perspicácia, astúcia etc., em seus múltiplos sentidos. Inúmeras são as palavras que podemos associar à observação e é fácil perceber que cada uma delas produz diferentes efeitos de sentido a quem observa e a quem estiver sendo observado, relacionado à heterogeneidade dos sujeitos e às relações entre eles. É possível perceber também que, dentre as palavras citadas, há aquelas que nos remetem a uma situação de conforto pelo fato de corresponderem a uma avaliação positiva ou ausência de avaliação, e outras que nos remetem a uma situação de desconforto por corresponderem à avaliação negativa ou à imposição de pontos de vista.

Nesse sentido, podemos relacionar o conceito de observação aos aspectos técnico, prático e crítico da construção do conhecimento. Quando pensamos no ato de advertir, restringir, ressalvar, por exemplo, é possível relacionar observação às características técnicas da reflexão, em que o resultado pode servir para apresentar receitas teóricas ao observado, com o objetivo de redirecionar seu fazer. Quando pensamos na observação como ato de comentar ou perceber, é possível relacioná-la às características práticas da reflexão, em que o resultado da observação pode servir como reorientação da prática sem a busca de embasamento teórico. Quando, no entanto, pensamos na observação como ato de anotar, analisar, explicar, é possível relacioná-la às características críticas da reflexão, em que o resultado pode servir como revisão da prática com fundamentação teórica e propósito de transformação dessa prática em âmbito social e cultural. É o que apontam autores como Mc Laren \& Giroux (1997) e Giroux (2000), ao afirmarem que práticas que conduzem à retomada consciente e fundamentada das ações docentes favorecem não somente o desenvolvimento do indivíduo, mas do contexto em que atua e da sociedade.

Quando nos referimos ao processo de observação pelo qual passa um professor quando tem em sua companhia um observador, certamente temos de considerar os efeitos de sentido que tal ato gera nesse professor, dependentes de sua constituição como sujeito, de sua história de vida pessoal e profissional, capazes de produzir diferentes sentidos ao ato de observar.

É importante que observação seja definida, portanto, na perspectiva crítica, uma vez que este trabalho se insere na teoria crítica de construção do conhecimento. O que seria, então, observação, dentro desse paradigma? Ora, se na perspectiva crítica de educação consideramos o sujeito ca- 
paz de fazer uso do conhecimento para modificar a si próprio e ao contexto em que se encontra inserido, tendo para isso que negociar significados e buscar constantemente o consenso com aqueles com os quais se relaciona, então podemos dizer que observação é o ato de olhar alguém ou alguma coisa cuidadosamente, a partir de critérios negociados, com o propósito de entender e fundamentar os aspectos observados, de modo a possibilitar mudanças factuais, conceituais, procedimentais e atitudinais ${ }^{3}$ dos envolvidos.

Assim sendo, quando nos referimos à atividade de observação da ação docente em sala de aula, é possível pensar que a partir desse processo professores podem se tornar aptos a modificar conscientemente suas aulas com base em análises fundamentadas, fazendo uso não somente de novos procedimentos e estratégias de aprendizagem, mas também dos 'velhos' procedimentos, uma vez analisados. Seu fazer estaria, então, orientado por atitudes coerentes com a concepção de ensino que privilegia o conhecimento numa visão sócio-cultural.

Nesse sentido, o processo de observação passa necessariamente pela presença de conflitos que exigirão que os envolvidos negociem critérios, em busca de consenso sobre os diferentes significados e sentidos gerados pelo ato de observar. Esse é um dos principais pontos de interseção entre a Teoria da Atividade e a atividade de observação: como utilizar conflitos e contradições como geradores de desenvolvimento. Dessa forma, apresento na seção seguinte uma discussão sobre conflito e como esse conceito articula-se à observação.

3. Os conceitos de conhecimentos factuais, conceituais, procedimentais e atitudinais baseiam-se em Zabala (1995). Conhecimentos factuais correspondem ao conhecimento de fatos, acontecimentos, situações, dados e fenômenos concretos. Conhecimentos conceituais referem-se a conjuntos de fatos, objetos ou símbolos que se organizam a partir de características comuns e articuladas, exigindo abstrações e relações com outros conhecimentos já construídos. Conhecimentos procedimentais estão relacionados ao saber fazer algo e o que define sua aprendizagem não é o conhecimento que se tem sobre algo, mas sim o domínio ao transferi-los para situações práticas. Conhecimentos atitudinais estão relacionados à natureza das atitudes do indivíduo nas diferentes situações a que é exposto em seus contatos grupais; envolvem valores e normas convencionadas no grupo social ao qual o indivíduo pertence. 


\subsection{Nas tessituras do conflito}

Em um processo de observação envolvendo professor e coordenador ou professores entre si, muitas são as situações em que, em função da história e de conhecimentos acumulados, os participantes têm diferentes interpretações, gerando o que chamamos conflitos. Estes, porém, não representam divergências relacionadas a aspectos corriqueiros e imediatos da atividade, mas relacionam-se às tensões historicamente situadas e à história de desenvolvimento tanto dos participantes quanto da atividade que desenvolvem.

Muitos são os autores que propõem discussões no sentido de esclarecer o conceito de conflito e neste trabalho apóio-me inicialmente em Schaffer (1992/2002) e, em seguida, em Schneuwly (1994) para encaminhar tal discussão.

Segundo Schaffer (1992/2002, p.296), determinados processos interacionais chamados "episódios de envolvimento conjunto parecem desempenhar um papel importante em influenciar o desenvolvimento". Para o autor, tais episódios correspondem a "qualquer encontro entre dois indivíduos em que ambos prestam atenção conjunta a algum tópico e agem conjuntamente sobre ele (p.295)." No entanto, isso não basta para explicar porque o desenvolvimento é acelerado por encontros sociais. Há fatores essenciais que podem ser investigados e, certamente, estão relacionados ao desenvolvimento ao qual Schaffer (1992/2002) se refere, dentre eles, quais as características desses encontros sociais e de quais mecanismos um interagente faz uso para provocar o outro buscando levá-lo a uma reorganização mental. É importante apontar também que, para que um encontro seja significativo, o tema abordado precisa ser considerado pelos interagentes como relevante, podendo indicar maior envolvimento na interação.

Para que ocorra um encontro significativo, diz ainda Schaffer (1992/ 2002), é preciso que os participantes percebam a relevância de um tópico para si próprios. Isso se dá por meio de ações de um dos parceiros, envolvendo o "chamar a atenção do outro" para a situação, por meio de dispositivos como fitar, apontar, manipular, e pelo uso da fala referencial, no sentido de, gradualmente, ir compartilhando o tópico em questão.

Pensando nas sessões de observação em sala de aula, o que pode significar para observado e observador o ato de observar? Imaginemos, por exem- 
plo, o ato de observar no sentido técnico (Van Manen, 1977; Liberali, 1994; Ninin, 2002), quando o objetivo do observador é encontrar receitas que possam ser oferecidas ao observado sobre suas ações. É possível dizer que tal evento pode ter, para o observador, o sentido de cooperação, enquanto que para o observado, o sentido de invasão, isto é, seu fazer é desconsiderado e outro lhe está sendo solicitado ou imposto. Esse pode ser um motivo de conflito entre ambos, relacionado à maneira como entendem observar.

Com base nas afirmações teóricas já apresentadas e na Teoria da Atividade, "o conflito pode ser considerado ingrediente essencial de qualquer envolvimento conjunto que visa a provocar mudança cognitiva [nos envolvidos] (Schaffer, 1992/2002, p.320)". Um conflito, no entanto, só pode ser resolvido se ocorrer uma reestruturação cognitiva, como resultado da interação social. Quando interagentes encontram-se em situação de conflito, o ideal seria que cada um lidasse com o ponto de vista do outro e que, de uma certa forma, pudessem reestruturar sua maneira de pensar e alterar suas estratégias. Mas também é claro que o desenvolvimento ou a reestruturação mental à qual o autor se refere não ocorre simplesmente pelo fato de os pontos de vista virem à tona nas interações, mas pode, sim, ocorrer em função de avanços que os participantes adotem em relação às suas próprias abordagens do conflito.

Isso nos leva a considerar o enfoque dado por Schneuwly (1994) ao conflito. Ao relacioná-lo à Zona Proximal de Desenvolvimento (ZPD), o autor busca articular o conceito, como definido por Vygotsky, ao ensino escolarizado. Para ele, ZPD é uma zona de conflitos do indivíduo consigo mesmo, com outros indivíduos e com o meio social, em busca de constante reorganização e aprimoramento das funções psicológicas superiores. Este é um conceito relacional que envolve, por um lado, a educação (entendida como as ações da escola) e por outro, o desenvolvimento. Assim, esse espaço de negociações e de conflitos estabelecido em relação às ações da escola e ao indivíduo, caracteriza, portanto, situações de desenvolvimento. E podemos considerar mais: se é por meio da linguagem que os conflitos são explicitados, esta certamente poderá ser a melhor opção para o tratamento de situações conflitantes.

Engeström (1987, p.174), situando os conceitos de conflito e ZPD na Teoria da Atividade, afirma que: 
Zona de Desenvolvimento Proximal é a distância entre as açoes presentes no cotidiano dos indivíduos e as novas formas de atividade social e historicamente constituídas que podem ser coletivamente geradas como solução para situações de impasse que fazem parte das ações cotidianas.

Nesse sentido, em relação à observação, é fundamental que participantes procurem conversar sobre conflitos surgidos, buscando esclarecer os significados, assim como a relevância do processo e do que está sendo observado. Tais esclarecimentos estarão pautados tanto na observação elaborada pelo observador, quanto em aspectos históricos e culturais nos quais estão apoiados os conhecimentos de cada um dos participantes. Essa conversa em busca de esclarecimentos e consenso apóia-se no que chamamos negociação. Embora este artigo não tenha como objetivo discutir as interações entre observador e observado, opto por discutir o conceito de negociação, uma vez que o processo de observação tem como propósito desencadear o processo de negociação.

\subsection{Nas tessituras da negociação}

Vamos novamente ao dicionário (Bueno, 2000, p.650): "negociar / negociação - ato ou efeito de comprar ou vender; permutar”. Também é possível associar negociar às palavras: agenciar, comercializar, distribuir, trocar, ceder, desfazer-se, renunciar etc. Da mesma forma como procedemos anteriormente ao falarmos sobre observação, tais palavras nos remetem a diferentes sentidos, construídos com base em nossa história de vida e de relacionamentos com outros seres humanos. Importante, portanto, se faz definirmos negociação no paradigma crítico de construção do conhecimento: negociação - ato em busca do consenso a respeito de conflitos, que considera os diferentes pontos de vista como pontos de partida, praticado pelos envolvidos num processo de interação, considerando não somente a voz de cada interactante, mas também os papéis que cada um exerce no contexto considerado, suas ações e os significados já construídos em relação ao conhecimento histórico e culturalmente acumulado.

No espaço de negociações é que ocorrem as mediações e a internalização dos conceitos científicos para o indivíduo. Considerando-se que o ensino possa disponibilizar instrumentos e criar condições para que sejam construídas novas funções psíquicas, podemos dizer que sua função é a de ativar o desenvolvimento mental do ser humano, ou seja, possibilitar mo- 
mentos de tensão e conflito entre aquilo que ele já sabe fazer e já conhece, e o futuro. Assim se caracterizam os eventos de observação: situações a serem negociadas envolvendo posicionamentos dos professores, relacionados aos seus conhecimentos prévios sobre concepção de ensino-aprendizagem, também construídos a partir da história de vida de cada participante e da história da docência.

Num processo de negociação, o que precisa ocorrer são discussões (Bridges, apud Brookfield \& Preskill, 1999) nas quais se evidenciam preocupações com a construção do conhecimento e se exige de cada um dos participantes a responsividade em relação às diferentes visões que explicitam. O propósito das discussões torna-se claro: alcançar um entendimento criticamente informado sobre o tópico em questão, sem deixar de perceber outras possibilidades de abordagem do mesmo tópico, e sem que cada um - observado e observador - se sinta unicamente avaliado em relação ao seu posicionamento pessoal.

Para Brookfield \& Preskill (1999), mutualidade, deliberação e avaliação são conceitos relevantes nos processos de negociação. Para os autores, mutualidade envolve a preocupação de uns para com os outros em relação àquilo que está sendo discutido. Agir com mutualidade significa perceber a necessidade de que todos participem, tendo espaço assegurado para pronunciamento. Pressupõem os autores que esse compromisso que assumimos perante os outros e sua participação promove a autoconfiança dos participantes e todos acabam por tornarem-se mais abertos e encorajados a fazerem seus pronunciamentos. Nessa perspectiva, observados não seriam considerados recipientes para depósito dos saberes de seus observadores, mas parceiros responsáveis na apresentação de argumentos, interpretação e reconstrução dos saberes em discussão.

Trago esse aspecto para as discussões pelo fato de que, muitas vezes, não somos capazes de dar real peso à mutualidade. Deveríamos, na verdade, exercitar a capacidade de trazer à discussão as vozes mais tímidas. Num processo de observação isso só se fará presente se os envolvidos experimentarem ambas as ações - observar e ser observado -, e sobre elas conversarem abertamente, estabelecendo critérios para o desenvolvimento das observações, significativos a ambos. Numa relação direta com a Teoria da Atividade, isso implicaria estarem, observado e observador, envolvidos na mesma atividade, tendo objetos da atividade convergentes, em função de um resultado compartilhado. 
Segundo Brookfield \& Preskill (1999), deliberação está relacionada ao fato de que participantes se colocam nas discussões oferecendo argumentos e contra-argumentos apoiados fortemente em evidências, e que tais participantes mantêm-se firmes em suas posições enquanto não encontram razões significativas para mudarem suas opiniões. No entanto, pessoas deliberativas também têm consciência de que ao entrarem em uma discussão devem estar atentas às diferentes posições que surgirem e que tais posições podem modificar suas opiniões originais.

Para Fishkin (1995), cientista político citado por Brookfield \& Preskill (1999), deliberar colaborativamente significa focalizar um tópico ou problema tão cuidadosa e completamente quanto possível, de forma que a gama de visões diferentes no grupo possa ser apresentada e defendida.

Numa sessão reflexiva ${ }^{4}$ pautada na atividade de observação, em que momentos assumimos papel de deliberadores? Como cada um dos participantes mostra-se atento ao dizer do outro e traz à discussão esse dizer? Como cada participante dá continuidade ao seu pensar a partir do pensar do outro? Nesse exercício de apoiar-se na voz do outro para prosseguir à interação, muitas vezes o que se faz é uma avaliação do dizer do outro, considerada aqui como perspectiva de reflexão para os envolvidos.

Brookfield \& Preskill (1999) apontam para o fato de que avaliação requer perspicácia daquele que a apresenta e precisa ser baseada em observações minuciosas, respeitosas. Se isso for respeitado, o nível de confiança entre os participantes tende a aumentar e tornar-se significativo para o crescimento não só do participante, mas também da comunidade que está em busca de se democratizar. Os autores alertam para o fato de que, caso a avaliação incorra em sentimentalismo ou inautenticidade, os padrões de trocas significativas acabam por diminuir.

4. Sessão reflexiva é definida neste trabalho como "momento de interação face-a-face entre observador e observado, cujo foco é analisar ações e práticas discursivas descritas por meio de diferentes instrumentos investigativos, ou apresentadas nas gravações em vídeo. Podem ser compreendidas como um espaço no qual o interdiscurso tem como objetivo principal desencadear a reflexão crítica. Não se nortearia somente por um roteiro de perguntas a serem feitas ao observado, mas sim, pela possibilidade de criar um espaço onde conhecer sobre o OUTRo na interação seria visto como aspecto de grande relevância no estabelecimento de vínculos, aspecto imprescindível à colaboração (Ninin, 2002)". 
Podemos pensar nisso como a possibilidade dessas trocas tenderem ao senso comum, o que muitas vezes ocorre em sessões reflexivas sobre observações em sala de aula. $\mathrm{O}$ observador solicita do observado que revele suas concepções teóricas e as coloque em discussão, mas, no entanto, sustentado pela relação de confiança com o primeiro, este explicita somente o senso comum. O observador sente-se, nesse momento, desencorajado. Assume papel acolhedor e esquece-se do papel de observador, desencadeador do contexto de reflexão para o outro. Isso merece cuidado especial daquele que observa e por esse motivo, a preparação de um roteiro de observação e, posteriormente, de possíveis indagações ao observado é fundamental, podendo minimizar o problema. O quadro a seguir orienta o trabalho de preparação da observação.

\section{Mapeando a observação}

Como discutido nas seções anteriores, o processo de observação sustenta-se no tripé: ato de observar, conflito e negociação, ancorados na perspectiva da Teoria da Atividade. Nesta seção, dimensiono a ação de observar, a partir de um quadro sustentado pelas características da reflexão técnica, prática e crítica (Van Manen, apud Ninin, 2002).

A visão crítica aqui discutida vai ao encontro da Teoria da Atividade, no sentido de que ambas buscam a compreensão do fazer humano contextualizado, situado histórica e culturalmente. A ação do professor observado transforma-se em artefato cultural para a atividade do observador e esta, por sua vez, transforma-se em artefato cultural para a atividade realizada após a observação, como dito anteriormente, a sessão reflexiva.

O processo de observação pode ocorrer tanto numa situação em que dois profissionais praticam a observação, sendo um o observado e outro o observador, quanto considerando-se a auto-observação, ou seja, o profissional observa-se a si próprio, a partir de gravação de suas ações em sala de aula. Ao sistematizar práticas de observar-se a si próprio, docentes não somente passam a avaliar seu próprio desempenho como também desenvolvem atitudes de controle sobre si, orientados por sua consciência. Monitorar as próprias ações passa a fazer parte de uma atividade complementar da docência e isto se dá através de técnicas como registro e narrativas de 
aulas, gravações em fita cassete ou vídeo, sessões de observação de aulas. A análise dos relatos ou das gravações, juntamente com o orientador da reflexão, possibilitará ao docente conhecer seu próprio processo de ensino.

\begin{tabular}{|c|c|c|c|}
\hline & Técnica & Prática & Crítica \\
\hline 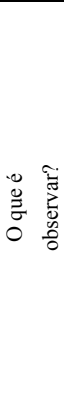 & $\begin{array}{l}\text { Ação que uma pessoa exerce sobre } \\
\text { outra, em busca de avaliar o fazer da } \\
\text { pessoa observada e de estabelecer } \\
\text { parâmetros a partir de aspectos } \\
\text { teóricos, para redirecionar suas } \\
\text { ações. Nessa perspectiva, os } \\
\text { artefatos culturais são determinados } \\
\text { por um conhecimento assumido } \\
\text { como "o correto" e existe um saber } \\
\text { prescrito, estabelecido por grupos } \\
\text { sociais dominantes que, de alguma } \\
\text { forma, exercem o domínio do } \\
\text { conhecimento considerado. Regras e } \\
\text { divisão de trabalho são aquelas } \\
\text { escolhidas pelo grupo dominante. }\end{array}$ & $\begin{array}{l}\text { Ação que uma pessoa exerce sobre } \\
\text { outra, com o propósito de comentar a } \\
\text { prática da pessoa observada, ou } \\
\text { compartilhar diferentes práticas que } \\
\text { possam facilitar a ação de outras } \\
\text { pessoas ou dos próprios envolvidos no } \\
\text { processo de observação. Nessa } \\
\text { perspectiva, diferentes artefatos } \\
\text { culturais podem ser considerados, } \\
\text { porém, sem rigor em relação aos } \\
\text { conceitos que os fundamentam. Basta } \\
\text { que sejam considerados pelo grupo } \\
\text { como instrumentos que podem } \\
\text { auxiliar a prática dos envolvidos. } \\
\text { Regras e divisão de trabalho podem } \\
\text { ser aquelas de consenso do grupo. }\end{array}$ & $\begin{array}{l}\text { Ação que uma pessoa exerce em } \\
\text { relação à outra, cujo foco é anotar } \\
\text { criteriosa e descritivamente as ações } \\
\text { da pessoa observada, para } \\
\text { posteriormente, juntas, analisarem, em } \\
\text { busca de entendimento e suporte } \\
\text { teórico, o material coletado. Nessa } \\
\text { perspectiva, os artefatos culturais } \\
\text { considerados relevantes são aqueles } \\
\text { cujo propósito se articula à concepção } \\
\text { sócio-cultural de educação. Regras e } \\
\text { divisão de trabalho não somente } \\
\text { relacionam-se à comunidade à qual } \\
\text { pertencem os envolvidos, como } \\
\text { também são negociadas para a } \\
\text { realização do processo de observação. }\end{array}$ \\
\hline 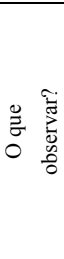 & $\begin{array}{l}\text { Aspectos conceituais, factuais, } \\
\text { procedimentais ou atitudinais do } \\
\text { fazer da pessoa observada, que não } \\
\text { estão sendo cumpridos ou que } \\
\text { podem servir como modelo a outras } \\
\text { pessoas. Nesse sentido, regras e } \\
\text { divisão de trabalho dominantes na } \\
\text { comunidade envolvida ditam os } \\
\text { parâmetros da observação. }\end{array}$ & $\begin{array}{l}\text { Aspectos conceituais, factuais, } \\
\text { procedimentais ou atitudinais do fazer } \\
\text { da pessoa observada, em busca de } \\
\text { facilitar a compreensão das ações } \\
\text { realizadas. Nesse sentido, regras e } \\
\text { divisão de trabalho podem rer } \\
\text { desconsideradas no processo re } \\
\text { observação. O importante ér a } \\
\text { facilitação do processo, por meio } \\
\text { daquilo que é observado. }\end{array}$ & $\begin{array}{l}\text { Aspectos conceituais, factuais, } \\
\text { procedimentais ou atitudinais do fazer } \\
\text { da pessoa observada, desde que } \\
\text { previamente combinado entre } \\
\text { observador e observado. Nesse } \\
\text { sentido, artefatos culturais funda- } \\
\text { mentam teoricamente as escolhas, } \\
\text { bem como regras e divisão de trabalho } \\
\text { da comunidade articulam-se e podem } \\
\text { ser negociadas. }\end{array}$ \\
\hline 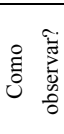 & $\begin{array}{l}\text { stabelecendo comparações com } \\
\text { odelos predeterminados, ditados } \\
\text { elas teorias e pelo conhecimento } \\
\text { ominante, a partir de regras } \\
\text { escritas e impostas. }\end{array}$ & $\begin{array}{l}\text { pessoa observada, con } \\
\text { relevantes para expl } \\
\text { prática, independente } \\
\text { teóricas que apóiam o }\end{array}$ & $\begin{array}{l}\text { Anotando detalhadamente e sem } \\
\text { emitir juízo de valor, as ações da } \\
\text { pessoa observada, em relação ao } \\
\text { aspecto previamente combinado, para } \\
\text { posterior análise e discussão. }\end{array}$ \\
\hline 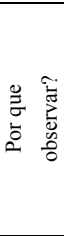 & $\begin{array}{l}\text { Porque existe um padrão que não } \\
\text { está sendo seguido pelo observado; } \\
\text { porque ao observar é possível } \\
\text { detectar aspectos relacionados aos } \\
\text { padrões preestabelecidos que não } \\
\text { estão sendo praticados pelo } \\
\text { observado; porque a observação } \\
\text { pode servir como modelo. }\end{array}$ & $\begin{array}{l}\text { Porque a partir da observação novos } \\
\text { procedimentos poderão surgir para } \\
\text { que sejam repetidos por outras } \\
\text { pessoas ou pelo próprio observador; } \\
\text { porque é preciso discutir a prática; } \\
\text { porque novas práticas poderão ser } \\
\text { estabelecidas a partir daquela que se } \\
\text { observa. }\end{array}$ & $\begin{array}{l}\text { Porque a observação pode levar à } \\
\text { compreensão das ações e sua } \\
\text { reorientação; pode propiciar aos } \\
\text { envolvidos um contexto para reflexão } \\
\text { sobre sua prática, em busca de } \\
\text { fundamentá-la; pode impulsionar o } \\
\text { docente a uma prática pedagógica que } \\
\text { priorize as transformações sociais, via } \\
\text { educando. }\end{array}$ \\
\hline 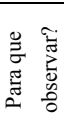 & as ações do & b. & $\begin{array}{l}\text { Para propiciar contextos de reflexão e, } \\
\text { conseqüentemente, de aprendizado, } \\
\text { aos envolvidos no processo: } \\
\text { observado e observador. }\end{array}$ \\
\hline 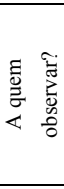 & $\begin{array}{l}\text { Àqueles que não correspondem aos } \\
\text { padrões estabelecidos por um grupo } \\
\text { dominante e precisam reformular } \\
\text { suas ações; aos que servem como } \\
\text { modelo para novos aprendizes, a } \\
\text { partir de padrões preestabelecidos. }\end{array}$ & $\begin{array}{l}\text { Àqueles que correspondem aos } \\
\text { padrões estabelecidos por um grupo } \\
\text { dominante e podem, portanto, } \\
\text { contribuir com novas práticas. }\end{array}$ & $\begin{array}{l}\text { Qualquer profissional, desde que } \\
\text { previamente combinada a sessão de } \\
\text { observação; àqueles com quem se } \\
\text { deseja discutir procedimentos e } \\
\text { encaminhamentos do fazer docente, } \\
\text { em busca de aprendizado e } \\
\text { desenvolvimento de ambos. }\end{array}$ \\
\hline 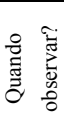 & $\begin{array}{l}\text { Quando propósitos pré-estabelecidos } \\
\text { não estão sendo cumpridos ou } \\
\text { quando é necessário moldar padrões } \\
\text { a partir do desempenho de uma } \\
\text { pessoa. }\end{array}$ & $\begin{array}{l}\text { Quando há necessidade de comparar } \\
\text { as práticas que as pessoas utilizam em } \\
\text { seu fazer. }\end{array}$ & $\begin{array}{l}\text { A qualquer momento escolhido pela } \\
\text { dupla envolvida, seja para analisar } \\
\text { situações de conflito ou de consenso. }\end{array}$ \\
\hline
\end{tabular}

Quadro 1: Mapeamento da observação com base nas características da reflexão e na Teoria da Atividade. 


\subsection{O que se pretende através da utilização do processo de observação das próprias ações}

A busca por desenvolvimento profissional ou aprimoramento das condições para lidar com diferentes situações em sala de aula, demonstra não a incompetência ou desconhecimento do professor, mas sim, a idéia de que, frente a mudanças na sociedade, o papel docente assumiu características distintas daquelas que marcaram sua formação acadêmica. Esse papel exige revisão sistemática e entende-se agora a profissão docente como uma prática crítico-reflexiva, embasada na autonomia e atualização constantes, que permitem ao professor criar, compreender e adaptar situações de aprendizagem adequadas aos alunos e sua realidade.

Apoiada na Teoria da Atividade, que considera o aspecto da historicidade do sujeito como de fundamental importância na compreensão e no desenvolvimento da atividade (Engeström, 1999a), é possível afirmar que para construir conhecimentos é necessário considerar-se o conhecimento prévio do professor e suas experiências pessoais, bem como sua disponibilidade para aprender. Os conhecimentos prévios do professor relacionam-se tanto à sua área específica de conhecimento, quanto à área pedagógica e aos sentidos construídos por ele sobre o ato de ensinar, resultantes também de sua história de aprendizagem.

Segundo Hernández (1998), a aprendizagem docente ocorre a partir de dois aspectos importantes, possíveis de serem articulados à Teoria da Atividade:

- à maneira como professores entendem sua própria docência, adquirida através de sua prática, suas representações ${ }^{5}$ e experiências, as quais norteiam suas ações e não se modificam em função apenas de cursos de formação, mas são, na verdade, geradoras de contradições historicamente situadas;

\footnotetext{
5. Conceito de representação considerado neste trabalho, entendido do ponto de vista da reflexão crítica: "A essa cadeia de significações construídas nas constantes negociações entre os participantes da interação e as significações, as expectativas, as intenções, os valores e as crenças referentes a: a) teorias do mundo físico; b) normas, valores e símbolos do mundo social; c) expectativas do agente sobre si mesmo enquanto ator em um contexto particular, denominamos representações (Celani \& Magalhães, 2002, p.311)”.
} 
- à importância de se conhecer a prática docente para se concluir sobre qual o papel das concepções do professor sobre sua tomada de decisões em sala de aula, em relação não somente ao ato de ensinar, mas às regras e à divisão de trabalho na comunidade onde age o professor.

$\mathrm{Na}$ esperança de aprender novidades que possam incorporar à sua prática pedagógica, docentes inscrevem-se em uma enorme quantidade de cursos de aprofundamento, mas, quase sempre, passado o tempo de euforia causada pelo que lá se desenvolve, percebem-se retomando sua prática cristalizada. Quando indagados sobre o que aproveitaram do curso, muitos respondem "Foi ótimo, mas não dá tempo pra fazer tudo isso na aula. Perco muito tempo." ou "Gostei do curso e até tentei aplicar nas minhas aulas, mas não deu muito certo. Tenho mais segurança fazendo como sempre fiz".

A reflexão sistematizada busca desarticular esse comportamento, dando subsídios aos docentes para que aprimorem seu desempenho e sejam capazes de avaliar cada uma de suas práticas com o objetivo de reaplicálas. O processo de observação das próprias ações, quando articulado a sessões de discussão com foco no material observado, oferece um feedback ao professor do que ocorre em suas aulas e a possibilidade de refletir de forma crítica sobre sua forma de ensinar. Espera-se com isso, que o professor passe de um estágio onde suas ações são movidas por impulsos, intuição ou rotina, para outro onde a reflexão crítica se sobrepõe ao senso comum, movendo-o em direção à autonomia e à elevação de seu nível de consciência sobre sua própria realidade e a dos alunos (Mc Laren \& giroux, 1997).

Observando-se, o professor pode direcionar suas ações visando minimizar a distância entre sua forma de ensinar e a realidade de seus alunos, fator fundamental no processo de ensino-aprendizagem. Pesquisas de Swaffar et al. (1982) mostram que, mesmo utilizando diferentes metodologias e acreditando estarem diversificando suas aulas, professores apresentam comportamentos comuns para ensinar. Observando-se mutuamente, torna-se possível a eles compreenderem melhor sua metodologia, além de possibilitar-lhes discutir sobre aspectos culturais e históricos que interferem em suas ações. 
Espera-se também, através do processo de auto-observação, que docentes e coordenadores pedagógicos dividam a responsabilidade da mudança na prática pedagógica, fator até então considerado mais preocupante para o coordenador. No processo de observação, quer visto como ação individual de auto-observação, quer como ação a ser compartilhada com outro profissional, o docente tem a possibilidade de conhecer-se em relação àquilo que já conhece de si próprio mas é desconhecido para os outros, ao que os outros sabem de si mas lhe é desconhecido, ao que todos já conhecem ou ao que ambos desconhecem, bem como de conhecer as representações que permeiam suas ações e àqueles que as observam. Através da auto-observação esses aspectos se revelam ao professor e podem explicar muitas de suas ações pedagógicas.

\subsection{Observação como instrumento para monitorar ações docentes}

Como já citado anteriormente, há diversos instrumentos que permitem ao professor monitorar suas ações: diário reflexivo pessoal, relato compartilhado, gravação de aulas em fita cassete ou vídeo, observação em parceria com outro professor. O foco deste artigo está nas sessões de observação, que muitas vezes decorrem de gravações de aula em vídeo ou áudio. A maior vantagem da gravação é a possibilidade de ser reexaminada várias vezes, possibilitando perceber detalhes no desempenho do professor e dos alunos, que muito poderão contribuir para com a interpretação das ações.

Após gravada a aula, a tarefa do professor consiste em assistir ao vídeo sozinho, lembrando-se de anotar todos os aspectos que considerar significativos para posterior revisão, seja consigo próprio ou com outro professor ou coordenador pedagógico. É interessante também que o professor escolha um trecho considerado intrigante e relate-o passo a passo, orientandose por questionamentos como:

- Qual a relação entre minha história pessoal e esse trecho que me intriga?

- Como esse trecho se relaciona às regras estabelecidas em minha escola?

- Que contradições consigo perceber entre o que eu considero importante em sala de aula e o que minha escola considera importante? 
Tais questionamentos podem revelar ao professor qual o papel de sua história pessoal e da história da atividade que exerce, em suas ações atuais. $\mathrm{O}$ mais relevante aspecto dessa tarefa consiste em encontrar respostas e explicações para as ações discutidas.

Antes de procederem a uma sessão de reflexão sobre o vídeo, é importante que a pessoa com quem essa sessão vá ocorrer também assista ao vídeo. No papel de observador também há muitos questionamentos a fazer e o orientador da reflexão deverá, da mesma forma que o observado, preparar suas anotações, com perguntas que propiciem, ao observado, momentos de reflexão fundamentada. Tendo em mãos esses relatos contendo o maior número possível de reflexões, parceiros podem conversar sobre a aula tentando encontrar caminhos alternativos e explicativos para as diversas situações discutidas.

Procedimentos de observação da ação docente em sala de aula nem sempre são considerados bem-vindos pelo professor que será observado. No entanto, através da estratégia de observação, duplas de professores ou professor e coordenador pedagógico podem, inicialmente, praticar o exercício de descrever uma aula para posterior análise. Para isso, é fundamental que ambos aprendam como observar: a partir de critérios preestabelecidos, de maneira cuidadosa, com sensibilidade e sem emitir juízo de valor sobre a situação observada.

A proposta de um observador não é julgar, avaliar ou criticar o professor observado, ou ainda oferecer sugestões, mas, simplesmente, coletar dados através da observação, para posterior análise e discussão. Assim, um professor poderá combinar com outro e permanecer em aula observando diferentes aspectos do processo de ensino, coletando o máximo de informações, sem prejulgá-las. O importante nesse processo é que observado e observador estabeleçam critérios para a sessão de observação e combinem sobre o que será observado (forma de comunicar-se do professor; um determinado aluno cujo relacionamento com o professor seja difícil; uma liderança de aluno que esteja interferindo no desenvolvimento da aula; o trabalho desenvolvido em relação ao conteúdo específico etc.), lembrando-se de não focalizar somente pontos fracos ou ruins da aula segundo o seu julgamento, mas fatos concretos que possam ser relevantes para o processo reflexivo crítico. Conforme já apresentado na seção 2, Quadro 1, os aspectos a serem observados podem referir-se a conhecimentos factuais, conceituais, proce- 
dimentais ou atitudinais, além dos relacionais. Uma vez escolhido um desses aspectos, é importante que o observador mantenha aí o seu foco de observação.

Um exercício interessante a ser feito por ambos participantes - observador e observado -, antecedendo o momento da observação, consiste em explicitar um ao outro qual sua experiência em relação a observar a aula de alguém ou ter alguém observando sua aula. Nesse momento ambos poderão colocar em discussão os aspectos que lhes são mais significativos para uma posterior sessão reflexiva, perguntando-se qual tipo de informação útil sobre o ensino poderia ser coletada.

Dentre os critérios combinados entre observador e observado, um dos mais importantes é a ética de ambos os participantes. Sigilo sobre as impressões e anotações feitas sobre a aula, sobre as discussões ocorridas em sessões de discussão, são fundamentais para que o processo de observação cumpra seu papel de colaborar no desenvolvimento dos docentes. Deve ficar claro ao professor observado que seu nome não será utilizado em discussões e reuniões com outras pessoas, quer no contexto da própria escola ou em outros. Toda referência direta ao professor ou aos seus alunos, formal ou informalmente, será feita anonimamente. Qualquer nota ou informação coletada durante a observação em sala de aula deverá sempre ser disponibilizada ao professor observado, em momento de sessão reflexiva.

\subsubsection{O que é importante prestar atenção e relatar em sessões de observação?}

É importante observar que as questões propostas a seguir tanto podem ser utilizadas em situações de observação quanto em gravações em cassete ou vídeo. Também podem ser utilizadas no caso de observações sobre conhecimentos factuais, conceituais, procedimentais ou atitudinais das ações docentes. Não são as únicas questões a serem consideradas no processo de observação, mas podem orientar o processo. Espera-se que os próprios envolvidos acabem por desenvolver outros questionamentos relevantes à ação de observar:

\subsubsection{Em relação à condução da aula}

- procedimentos do professor em relação à condução das tarefas / estratégias desenvolvidas 
- maneira como o professor questiona os alunos

- maneira como o professor responde às dúvidas dos alunos

- envolvimento do professor durante o tempo em que os alunos executam tarefas

- tipo de tratamento que o professor dá aos erros dos alunos

- exposição das tarefas pelo professor aos alunos

- apresentação dos objetivos das tarefas aos alunos

- maneira como as diferentes partes da aula se relacionam?

- maneira como o professor "fecha" o assunto tratado, ao final da aula

2.2.1.2. Em relação às interações em sala de aula

- como os alunos interagem com o professor e entre si

- como o professor procura manter o interesse dos alunos

- como o professor cria zonas de conflito para que os alunos interajam uns com os outros

- como o professor medeia as situações de negociação entre os alunos?

- como o professor dá consideração à voz dos alunos

2.2.1.3. Em relação à socialização do conhecimento

- critérios utilizados para formação de grupos

- como o professor expõe as tarefas para os grupos

- como o resultado de tarefas em grupo é compartilhado

- como propostas dos alunos são discutidas pelo professor com a classe

- como são resolvidas situações de impasse em relação ao conteúdo trabalhado

2.2.2. O que é importante ter como critério no momento de combinar procedimentos de observação?

O estabelecimento de critérios para os procedimentos de observação de ações do docente pode ser considerado como um elemento organizador do processo, que contribui para que o professor observado sinta-se seguro em relação ao que ocorrerá em sua sala de aula, e o observador sinta-se 
autorizado a proceder com a observação, sem sentir-se invadindo a privacidade de seu colega. Assim, alguns pontos importantes são apresentados a seguir:

\subsubsection{Observação deve ser um processo sistematizado na escola}

Como ponto de partida, é fundamental que os processos de observação sejam organizados de modo sistemático nas escolas. Caso aconteçam esporadicamente, sem sistematização, corre-se o risco de serem entendidos apenas como modismos ou como procedimentos de verificação da atuação docente. Dessa forma, o mais adequado seria a elaboração junto aos docentes, de um plano de observação, que respondesse com transparência, às perguntas: $\mathrm{O}$ que vamos observar?, Como vamos observar?, Por que vamos observar?, Para que vamos observar?, O que será feito a partir da observação?

\subsubsection{Observação deve ter um foco}

O valor da observação aumenta se o observador sabe o que procura. Uma observação que termina com um comentário tal como "Oh, esta foi realmente uma ótima aula!" não está particularmente ajudando aos envolvidos. Mas, por que um foco pode ser útil? Imaginemos que após a sessão de observação, professor observado e colega observador ou coordenador pedagógico conversem sobre aquilo que foi observado. Caso não se tenha escolhido um foco, inúmeros serão os aspectos sobre os quais os envolvidos terão de conversar, todos eles fundamentais para o aprendizado e desenvolvimento de ambos. No entanto, professores e coordenadores não têm disponível um tempo que lhes permita conversar sobre muitos e muitos assuntos. Também muitos serão os conceitos teóricos envolvidos e, para discuti-los, os participantes deverão não somente dispor de tempo, como também terão de articular tais conceitos às suas ações, o que não será fácil. O propósito de ter um foco para a observação, é, na verdade, limitar o campo de negociações, permitindo que um maior número de inferências possam ser feitas entre a ação real ocorrida e os conceitos teóricos a ela diretamente relacionados. Consideremos, por exemplo, a possibilidade de observar como um professor ensina um determinado conteúdo e como é que se relaciona com seus alunos durante a aula. Nessa proposta, podemos pensar em dois focos: um deles em relação ao conhecimento conceitual e ao processo de ensino-aprendizagem e outro, quanto à relação professor- 
aluno. Para dar conta dessa discussão, seriam necessárias teorias de aprendizagem e teorias psicológicas sobre relação professor-aluno. Notem que ambas são extensas e exigiriam um bom número de horas para que fossem discutidas com profundidade. Caso o foco esteja em ambos os aspectos, existe grande risco de não se discutir nem bem um, nem bem outro.

\subsubsection{Observadores devem utilizar procedimentos específicos}

Aulas são complexas, com muitas tarefas ocorrendo simultaneamente. A escolha do foco para observação não deverá ser feita repentinamente, mas de maneira criteriosa, pelo observador, em acordo com o observado. Os procedimentos a seguir são sugestões que orientam nesse sentido.

Marcar reunião para orientação pré-observação. Antes de iniciar a observação os envolvidos devem encontrar-se para discutir: natureza da observação a ser feita em aula, tipo de material usado para o ensino, abordagem do professor sobre o ensino, perfil dos alunos da classe, padrões típicos de interação, participação em aula etc.

Identificar o foco da observação. Alguns exemplos:

- organização da aula - início, estrutura, condução;

- administração do tempo pelo professor - distribuição do tempo para diferentes tarefas propostas;

- desempenho dos alunos na realização de tarefas - estratégias, procedimentos e padrões interacionais utilizados durante a realização de uma tarefa;

- tempo da tarefa - período de tempo no qual os alunos estão efetivamente envolvidos na tarefa;

- perguntas do professor e respostas dos alunos - tipo de questões que o professor faz durante a aula e modo como os alunos respondem;

- desempenho dos alunos durante trabalho em dupla - meio através do qual os alunos completam uma tarefa em dupla, respostas que eles dão durante a execução da tarefa e tipo de linguagem que utilizam;

- interações em sala de aula - padrões de interação professor-aluno e aluno-aluno, durante a aula;

- trabalho em grupo - tempo de realização e dinâmica das tarefas desenvolvidas em grupo. 
Desenvolver procedimentos para usar durante a observação. Alguns exemplos:

- tempo marcado - observador anota comportamentos específicos mostrados num determinado intervalo de tempo da aula;

- formulários - observado e observador podem elaborar juntos um instrumento contendo aspectos focais a serem observados;

- descrição - observador descreve o que ocorreu durante a aula;

- quando a observação já ocorre sistematicamente entre professores, procedimentos de alerta podem ser combinados entre observador e observado.

Marcar uma sessão de pós-observação. Os envolvidos no processo de observação devem encontrar-se tão logo quanto possível após a aula observada. O observador deve oferecer ao observado seu relato contendo informações coletadas durante a aula, iniciando então uma sessão reflexiva onde serão discutidos os aspectos relatados. Observador deve preparar-se para esse encontro, fazendo uma leitura cuidadosa de seu relato, questionando-o, preparando perguntas a serem feitas ao observado, no sentido de propiciar a ele a possibilidade de, distanciando-se de sua ação, revisá-la, buscando explicações nas teorias formais. Os questionamentos propostos são importantes para que o professor observado possa compreender o papel social de sua aula e, posteriormente, adotar uma postura crítica buscando práticas que consolidem seu desenvolvimento (Ninin, 2002).

\section{Desvendando a observação}

Nesta seção, discuto diferentes recortes de sessões de observação, com o propósito de entender o papel da linguagem na construção dos conhecimentos do observador, em situações pedagógicas. Para isso, recorro à Lingüística Sistêmico-Funcional e apresento uma breve discussão sobre ela, a fim de situar o leitor no referido contexto.

Segundo Halliday (1985/1994), linguagem é um recurso utilizado pelos seres humanos para criar significados, ou seja, ela é um sistema semiótico que oferece opções aos falantes para que expressem seus significados. Ainda para Halliday (1985/1994), a linguagem é multifuncional e pode ser vista como um instrumento sociossemiótico, pois tanto depende dos pro- 
pósitos comunicativos daquele que a utiliza quanto de suas condições e relações num dado contexto. Ocorre por meio de escolhas do falante, disponíveis a ele como se em uma rede de opções inter-relacionadas, onde cada uma delas tem seu significado relativo, isto é, sempre quando comparada a outras escolhas.

Os enunciados por nós produzidos para a expressão e significados acontecem a partir de três níveis de linguagem:

- usamos a linguagem para interagir, para estabelecer e manter relações com outras pessoas, para influenciar seu comportamento, para expressar nosso ponto de vista sobre as coisas, pedir o ponto de vista de outras pessoas, bem como tentar mudá-lo; caracteriza-se, dessa forma, a metafunção interpessoal da linguagem;

- usamos a linguagem para falar sobre nossa experiência de mundo, para descrever estados, eventos e entidades nele envolvidas, para apresentar a imagem mental que temos da realidade, para expor o conteúdo daquilo que pensamos e/ou queremos dar a conhecer a outras pessoas; caracteriza-se, dessa forma, a metafunção ideacional ou experiencial da linguagem;

- usamos a linguagem para organizar nossas mensagens, para dar forma às nossas interações e conceituações, adequando tais mensagens em relação a outras e ao contexto maior no qual estamos inseridos, falando ou escrevendo; caracteriza-se, portanto, a metafunção textual da linguagem.

Halliday \& Hasan (1989, p.23) apontam como essencial a visão do entrelaçamento das metafunções no discurso: toda sentença é multifuncional, como já dito anteriormente, e compreendê-la requer uma visão em diferentes ângulos, com cada perspectiva contribuindo para a compreensão mais ampla da sentença, em relação ao contexto em que se insere.

Assim, estudar a forma como as pessoas fazem uso de: sistemas de modo (função interacional envolvendo os papéis de fala) e de modalidade (função pessoal, envolvendo expressões modais e avaliativas) (Thompson \& Thetela, 1995); sistema de transitividade (processos, seus participantes e as circunstâncias associadas aos processos); e sistema de temas (tema 
como ponto de partida da mensagem e rema como a informação nova sobre o ponto de partida), é fundamental para a compreensão dos significados envolvidos nas situações de uso da linguagem.

Um exemplo em que os componentes interpessoal, ideacional e textual se entrelaçam na produção do significado de uma sentença pode ser o que segue, selecionado do corpus de análise deste trabalho: "Eu trabalho com o texto $X$ em todas as turmas da $7^{a}$ série".

- eu é sujeito na oração; é o tema; é a pessoa sobre quem o papel foi projetado, isto é, a pessoa que emitiu o enunciado não só participa do evento lingüístico como atribui a si própria o papel de ator no evento;

- trabalho corresponde tanto a um processo material (fazer alguma coisa como por exemplo, oferecer roteiro para os trabalhos, separar materiais, preparar estratégias para a aula etc.) quanto a um processo mental (fazer uso da experiência pessoal e do conhecimento sobre o assunto para desenvolver algo junto aos alunos);

- texto $\mathrm{X}$ corresponde tanto à meta do processo, a quem a ação de trabalhar se dirige, quanto ao fenômeno sobre o qual as experiências do interactante eu exercem influência.

Para Halliday \& Hasan (1989), a metafunção interpessoal realiza-se gramaticalmente por meio dos sistemas de modo e de modalidade. A sentença é organizada como um evento interativo envolvendo o falante ou escritor e sua audiência. Ao falar, o falante faz suas escolhas e adota um papel particular no discurso, que se relaciona àquilo que deseja em relação ao papel de seu ouvinte. $\mathrm{O}$ sistema de modo estabelece as relações entre os participantes, ou seja, estabelece os papéis de fala; o sistema de modalidade estabelece as avaliações dos participantes sobre uma mesma mensagem.

Assim, consideramos que, em relação ao modo, os papéis de fala materializam-se lingüisticamente pelas funções:

- dar (falante) / aceitar ou rejeitar (respondente)

- exigir (falante / conformar-se ou recusar (respondente)

- declarar (falante) / concordar ou contradizer (respondente)

- perguntar (falante) / responder ou negar (respondente) 
Em relação à modalidade, Halliday \& Hassan (1989) consideram a modalização (1) e a modulação (2), que aparecem em graus alto, médio e baixo, e que se constituem lingüisticamente por meio de:

(1)

- operador modal do grupo verbal (no elemento finito) - "Nós, professores, gostaríamos muito de receber orientações mais precisas da coordenação";

- adjunto modal de probabilidade - "Estamos cada vez mais certos sobre o que a escola quer de nós professores";

- adjunto modal de freqüência - "Nunca estamos seguros sobre os procedimentos da coordenação”.

- operador finito modal que expressa obrigação - "Os alunos têm que desenvolver o hábito de estudar elaborando sínteses";

- expressão de inclinações - "Eu quero muito ajudar meus alunos a se saírem melhor nas avaliações";

- expressão de capacidade - "Posso formar um aluno competente aqui na escola, mas para isso todos nós precisamos colaborar".

A metafunção ideacional, segundo Halliday (1985/1994), realiza-se gramaticalmente por meio do sistema de transitividade, ao qual correspondem os processos, os participantes dos processos e as circunstâncias associadas aos processos. Eggins (1994, p.229) reafirma essa posição de Halliday, ao dizer: "Assim, descrevendo a gramática da oração como representação, nós não estamos somente descrevendo as diferenças entre tipos de processos, mas também estamos associando as diferenças aos papéis funcionais dos participantes, e à possível seleção de ciscunstâncias".

O quadro a seguir apresenta os processos considerados por Halliday (1985/1994) e sustentados pelas discussões de Eggins (1994): 
Processos: 3 grupos semânticos principais - materiais, mentais e relacionais

Categorias intermediárias: comportamentais, verbais e existênciais

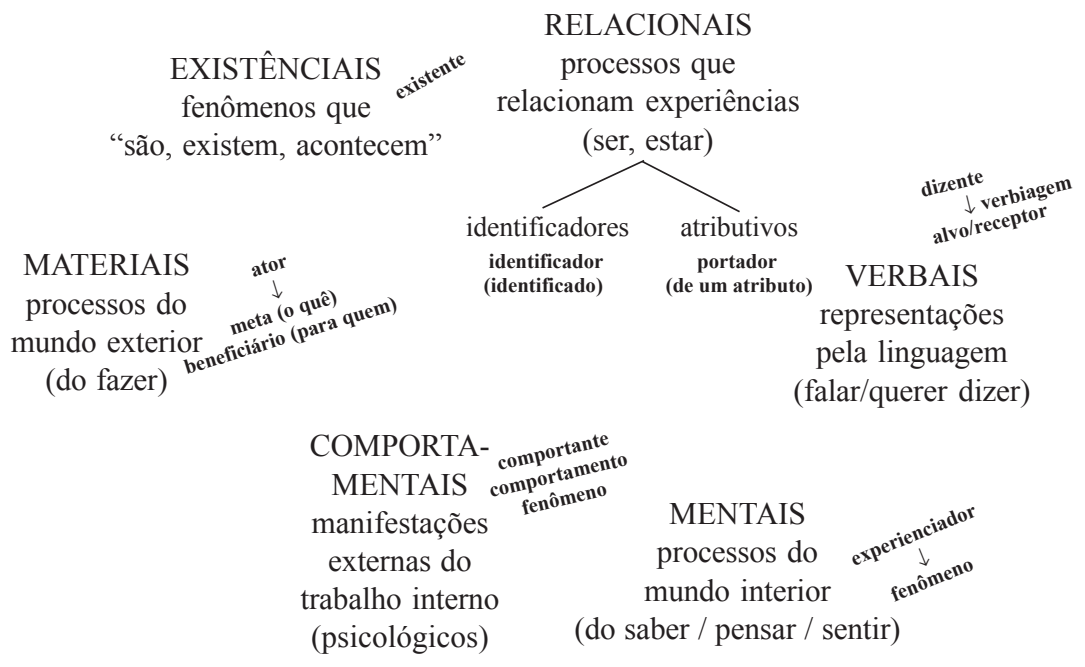

Figura 1: Processos Verbais.

Ao examinar a transitividade, é possível perceber significados experienciais dos participantes sobre o mundo, sobre sua experiência, sobre como percebem e experienciam aquilo que fazem / precisam fazer, e, especialmente, sobre como vai se construindo a rede de significados sobre o que está sendo dito e como as mudanças vão ocorrendo. Para Eggins (1994, p.270), "a tarefa de construir um mundo de experiências através da falar encarrega-se simultaneamente da tarefa de expressar e explorar o papel das relações e atitudes". Na interação, não somente falamos sobre algo, como falamos a alguém e isso ocorre por meio de estruturas lingüísticas relacionadas tanto à função transitividade quanto à função modo.

A metafunção textual realiza-se gramaticalmente por meio do sistema temático ou estrutura de temas. Segundo Halliday (1985/1994), em todas as línguas é possível identificar a presença das mensagens e como elas se organizam num evento comunicativo: um elemento é enunciado como tema e combinado com outros elementos, dando forma à mensagem. Halliday considera o tema como sendo o elemento de partida da 
mensagem e o restante da mensagem é denominado rema, isto é, o desenvolvimento do tema.

É importante ressaltar que a estrutura temática permite-nos descobrir pistas sobre o desenvolvimento do texto e é fator primordial na construção da coesão textual. Ainda: a estrutura temática de uma oração está diretamente relacionada ao modo da oração (declarativo, interrogativo ou imperativo) e se revela ao leitor de forma marcada (a forma não usual na língua alvo, que foge ao padrão convencional) ou não marcada (a forma padrão na língua alvo). A maneira como a estrutura temática se desenvolve pode interferir no significado do texto. O exemplo a seguir mostra isso:

\section{Contexto:}

- participantes: professor observado, professor observador;

- conversa sobre o que seria importante observar numa aula em que alguns problemas disciplinares vêm ocorrendo;

- situação 1: Professor observador: "Mas alguém já havia pensado sobre essa classe antes?" // Professor observado: "Eu já havia falado sobre esse problema para o coordenador, mas ninguém fez nada pra resolver."

- situação 2: Professor observador: "Mas alguém já havia pensado sobre essa classe antes?" // Professor observado: "Ninguém fez nada pra resolver esse problema da HTPC, mas a gente já tinha falado sobre ele."

É possível inferir que na situação 1, cujo tema na fala do professor observado corresponde a eu, em resposta à indagação do professor observador sobre quem já havia pensado sobre o problema, esteja sendo atribuído ao professor observado o papel projetado de apontar o problema aos demais participantes e responsabilizá-los pela não resolução, enquanto que na situação 2 , cujo tema se apresenta como ninguém, a responsabilidade pela ação parece ser assumida também pelo professor observado, ao complementar seu dizer com a gente, incluindo-se no grupo dos participantes.

Com base nesses pressupostos, a seção a seguir procura discutir alguns recortes de observações em situação docente, considerando as metafunções ideacional, interpessoal e textual. 


\subsection{A linguagem e as situações de observação}

Esta seção objetiva discutir alguns recortes de sessões de observação focalizando o papel do observador. Dez sessões de observação foram analisadas sendo que três tiveram como observador o professor coordenador pedagógico (observações E, G e J); duas tiveram como observador o próprio professor responsável pela aula, que analisou o vídeo de sua própria aula (observações $\mathrm{C}$ e I); e cinco tiveram como observador um professor colega (observações A, B, D, F e H). Em três sessões de observação o observador disse não haver combinado sobre o foco da observação com o professor observado (observações E, H e J). Em paralelo, os observadores apresentaram relatos sobre o sentido atribuído ao processo de observação, discutidos nas próximas seções.

Considerando o propósito deste artigo, a análise procurou focalizar as ações do observador e não as do observado. Embora considere a importância de analisar todos os processos decorrentes de um texto, incluindo-se aí as orações projetadas relatadas e citadas, neste estudo opto por analisar apenas as orações projetadas relatadas e explico o porquê. O objetivo do artigo é caracterizar os processos de observação e discutir a linguagem utilizada pelo observador. Nos dados coletados, o discurso direto apresentado que corresponde às orações projetadas citadas, é proferido pelo participante observado e não pelo observador. Este apenas cita o discurso do colega observado. Como já afirmei anteriormente, neste artigo analiso o discurso do participante observador, embora considere que em se tratando da formação dos professores envolvidos, ambos os discursos tenham igual importância e devam ser analisados, pois é na articulação de ambos que se torna possível entender como se dá a negociação dos sentidos apresentados pelos participantes e a construção de novos significados. Privilegio aqui o discurso do observador, deixando para outro momento de estudo a discussão dos processos de negociação entre observador e observado.

As orações projetadas relatadas são analisadas, uma vez que compõem o discurso do participante observador. Um exemplo pode melhor justificar a necessidade de analisar as orações projetadas relatadas. Suponhamos as situações a seguir, representativas de um mesmo evento em sala de aula: (A) em que o observador utiliza oração projetada relatada e (B) em que o observador utiliza oração projetada citada. 
(A) Professora parece duvidar do trabalho da aluna e diz [que não está entendendo o que a aluna fez].

(B) Professora diz: "Isso está certo? Como você fez isso?"

No exemplo (A) há um processo mental (parece duvidar) cujo experienciador é professora e o fenômeno é do trabalho da aluna. Um segundo processo verbal (diz) aparece no trecho considerado, estando o dizente implícito (professora), seguido de uma oração projetada relatada cujo processo escolhido pelo observador é mental (está entendendo), sendo a própria professora o participante experienciador e o que a aluna fez, o fenômeno.

No exemplo (B) aparece o processo verbal diz, cujo dizente é professora, seguido de oração projetada citada. Nessa oração, temos como processo está, relacional identificativo intensivo, sendo isso o identificado e certo o identificador. Um segundo processo aparece ainda na oração projetada citada: fez - processo material que tem como ator você e como meta isso.

Podemos observar que as escolhas por processos no caso do observador em (A) (mental, verbal, mental), diferentemente das escolhas do observador em (B) (verbal, relacional, material), carregam o ponto de vista do observador, uma vez que o observador A faz uso de escolhas lexicais avaliativas para relatar o discurso do professor, enquanto B não o faz. Por esse motivo, analiso as orações projetadas relatadas, pois elas revelam as escolhas do observador e seus sentidos, foco deste trabalho.

Como critério para análise das sessões de observação, optei por analisar primeiramente os processos verbais (transitividade), buscando respostas às perguntas: (a) quais os processos escolhidos pelo observador, para designar as ações do professor observado? (b) como variam essas escolhas proporcionalmente? (c) quem são os participantes desses processos? (d) em que circunstâncias ocorrem? Como segundo passo, optei por analisar os papéis de fala (interpessoalidade), buscando resposta à pergunta: quais os papéis de fala escolhidos para designar as ações do professor observado, ou seja, como o observador projeta papéis em relação ao participante observado? Finalizando a análise, procuro itens lexicais que caracterizam atitudes e responsabilidades, analisando modalidade e modalização.

Ao final das discussões teço considerações e discuto, ainda que preliminarmente, algumas características presentes nos registros, em relação a professor observando professor, coordenador observando professor e auto- 
observação. Embora isso não seja o foco do artigo, as análises apontaram aspectos que considero relevantes e que podem orientar novos estudos a respeito da atividade de observação.

Os trechos apresentados nesta seção procuram mostrar como a análise com base na gramática sistêmico-funcional pode colaborar para com a organização de critérios aos observadores, fornecendo-lhes parâmetros para a produção dos textos de observação, que propiciem aos participantes contextos não avaliativos, mas capazes de gerar interações entre observador e observado em situações de estudo e formação contínua. A análise procura mostrar também como os elementos da atividade se interrelacionam nos eventos de linguagem, do ponto de vista do observador.

Divido as discussões a seguir considerando aspectos distintos: primeiramente, utilizo textos produzidos pelos observadores sobre o que observaram em sala de aula; em seguida, utilizo relatos dos observadores quando foram questionados sobre observação; por último, procuro destacar os elementos da atividade nos textos produzidos pelo observador. Para que o leitor possa melhor compreender as discussões, apresento no Anexo 1 uma síntese explicativa das relações entre os sujeitos envolvidos nas sessões de observação.

\subsubsection{Observador relata a aula observada}

Em relação à transitividade, as análises das sessões de observação revelaram uma concentração de processos verbais e materiais, como mostra a tabela a seguir:

\begin{tabular}{|c|c|c|c|c|c|c|c|}
\hline Observação & $\begin{array}{c}\text { \% de processos em } \\
\text { relação ao número de } \\
\text { palavras do texto }\end{array}$ & $\begin{array}{c}\text { \% processos } \\
\text { materiais }\end{array}$ & $\begin{array}{c}\text { \% processos } \\
\text { verbais }\end{array}$ & $\begin{array}{c}\text { \% processos } \\
\text { mentais }\end{array}$ & $\begin{array}{c}\text { \% processos } \\
\text { relacionais }\end{array}$ & $\begin{array}{c}\text { \% processos } \\
\text { materiais }\end{array}$ & $\begin{array}{c}\text { \% processos } \\
\text { comportamentais }\end{array}$ \\
\hline A & 17.1 & 9.7 & 61.9 & 8.8 & 1.8 & 2.7 & 15.0 \\
\hline B & 18.3 & 19.2 & 50.7 & 15.1 & 11.0 & 0.0 & 4.1 \\
\hline C & 14.5 & 34.8 & 30.4 & 30.4 & 4.3 & 0.0 & 0.0 \\
\hline D & 18.9 & 45.2 & 41.9 & 3.2 & 3.2 & 0.0 & 3.2 \\
\hline E & 20.0 & 32.3 & 33.3 & 14.6 & 5.2 & 3.1 & 11.5 \\
\hline F & 15.5 & 28.9 & 38.9 & 5.6 & 5.6 & 1.1 & 20.0 \\
\hline G & 23.8 & 23.3 & 40.3 & 17.0 & 13.1 & 1.1 & 5.1 \\
\hline H & 13.5 & 41.9 & 19.4 & 16.1 & 16.1 & 0.0 & 6.5 \\
\hline I & 123 & 15.8 & 28.3 & 38.8 & 11.8 & 2.0 & 3.3 \\
\hline J & 17.5 & 22.6 & 11.3 & 24.2 & 17.7 & 3.2 & 21.0 \\
\hline
\end{tabular}


No caso da observação A, havia uma regra combinada entre observador e observado, sobre o foco da observação: "como o professor questiona os alunos". O professor observador manteve-se atento ao foco, apresentando, em orações projetadas citadas, perguntas feitas pelo professor observado aos seus alunos, como por exemplo:

\footnotetext{
Professora faz (p.Ve) a primeira pergunta: “Em que momento ...” (...)

Professora pergunta (p.Ve): “Acabou a Segunda Guerra. Quem foram os vencedores?” (...)

Professora repete (p.Ve) a pergunta: "em que momento você percebe ...?" e continua explicando (p.Ve), respondendo (p.Ve) essa pergunta que fez. Fala (p.Ve) por uns minutinhos e faz (p.Ve) mais uma pergunta: "Em outros países eles entraram, como por exemplo, o Chile. O que Pinochet fez?" (...)

Professora faz (p.Ve) mais uma pergunta: "Por que Pinochet dá o golpe militar? Quem está por trás do golpe militar?"
}

Observação A

No decorrer da observação o observador faz uso desse recurso 12 vezes e analisando as orações citadas referentes às perguntas do professor observado, é possível perceber a importância do discurso citado (25.5\% do texto correspondem ao discurso citado). Como o observador apresenta exatamente o que foi dito pelo observado, é possível, por exemplo, estudar o tipo de perguntas apresentadas pelo professor aos alunos. Isso propiciaria um contexto para que observado e observador conversassem sobre a qualidade das perguntas feitas, o foco das perguntas, que tipo de aprendizagem elas gerariam nos alunos etc. Neste exemplo, 7 das 12 perguntas feitas pelo observado referem-se ao conhecimento factual, 4 ao conhecimento conceitual e 1 ao conhecimento procedimental. Sendo possível reconhecer isso, uma conversa entre professor observado e professor observador poderia orientar-se por entender a importância desses tipos de conhecimento na aprendizagem dos alunos. Caso o observador tivesse recorrido a orações projetadas relatadas, não teríamos a mesma certeza, uma vez que o discurso relatado não necessariamente traz as marcas lingüísticas reais, mas traz, sim, as marcas lingüísticas representativas da realidade, do ponto de vista daquele que produz o texto. Tais escolhas lexicais referem-se às escolhas do observador, que não necessariamente são as mesmas do professor observado. Daí a importância do discurso citado nos textos de observadores.

O mesmo ocorre no texto do observador B: $33.9 \%$ do texto correspondem ao discurso citado, sendo 10 as perguntas apresentadas. Já neste exemplo, as perguntas concentram-se no conhecimento conceitual (6 das 10 perguntas), sendo 4 relacionadas ao conhecimento factual. 
Professora cola (p.Ma) na lousa o sol e vários círculos e começa a relembrar (p.Ve) com os alunos o Sistema Solar. Pergunta (p.Ve): "Quem se lembra quem está mais pertinho do sol?" (...)

Professora diz (p.Ve): "O que vocês acham?” (...)

Professora pergunta (p.Ve): "E depois dele, quem se lembra?"

Professora (...) Pergunta (p.Ve) para a classe: "Quem vem primeiro?"

Uma aluna responde (p.Ve): "O a". Outro aluno diz (p.Ve): "Não tem planeta com a".

A professora diz (p.Ve): "Então como é que nós vamos resolver isso?"

Um aluno diz (p.Ve) [que é a Terra] e a professora diz (p.Ve): “O que vocês acham, classe?” (...)

Ao chegar na letra M, encontram (p.Me) dois planetas e a professora diz (p.Ve): "Agora vocês vão ter de decidir sobre qual vem primeiro. Combinem com o coleguinha do lado e me digam. Um minutinho pra pensar com o coleguinha".

É possível inferir que, pelo fato dos observadores terem mantido sua atenção no foco combinado para a observação, tenha havido maior concentração nos processos verbais (61.9\% em A e $50.7 \%$ em B). Destaca-se em ambos os textos, o processo verbal diz, seguido de pergunta ou faz (uma pergunta).

Em ambas observações, analisando a estrutura temática encontramos como tema primeiramente a palavra professora, seguido da palavra aluno. Os processos mentais que aparecem nos textos referentes às observações não apresentam o observador como experienciador, mas sim o professor observado. São processos mentais de cognição, acompanhados de fenômenos que retratam fatos. Os demais processos são acompanhados, em sua maioria, de circunstâncias de localização ou extensão, como por exemplo:

Professora completa (p.Ve) a fala da aluna e retoma (p.Ve) a explicação sobre os Estados Unidos. falando (p.Ve) por mais 10 minutos.

(...) Professora faz (p.Ve) pergunta após essa explicação. (circ. de extensão - temporal)

(...) Professora retoma (p.Ve) a explicação sobre quem venceu a guerra. (circ. de assunto)

(...) Alunos riem (p.Co) da situação e um aluno diz (p.Ve) em voz alta: "Ei, volta pra cá, meu!" (circ. de causa-razão) (circ. de modo-qualidade)

Observação A

Isso pode significar que o observador não emite juízo de valor sobre aquilo que observa.

As observações C e I correspondem ao processo de observação em que os professores gravam suas aulas e em seguida observam-se através do vídeo. Nesses textos cresce o percentual de processos mentais, principalmente em I, onde a professora relata o que observa e, em seguida, comenta sua própria ação. 
Momento em que explico (p.Ve) o trabalho aos alunos: digo (p.Ve) a eles que vamos fazer (p.Ma) um painel (...) e que eles devem organizar (p.Co) os problemas por assunto. Cada grupo deve separar (p.Co) por assunto os problemas encontrados, antes de colocar (p.Ma) no painel. Um aluno me pergunta (p.Ve) sobre a divisão dos grupos, como é (p.Re) que devem organizar-se (p.Re). Respondo (p.Ve) que eles podem escolher-se (p.Co) livremente. Os alunos já começam a movimentar-se (p.Ma) pela sala, tentando encontrar (p.Ma) os colegas com quem vão trabalhar. Decidem trabalhar (p.Me) sentados no chão. Um outro aluno me pergunta (p.Ve) quais os assuntos que deverão orientar (p.Me) a separação das reportagens. Respondo (p.Ve) que isso será decidido (p.Me) no decorrer do trabalho. Analisando (p.Me) isso que aconteceu (p.Re), acredito (p.Me) que poderia ter feito (p.Me) de forma diferente. Primeiro: não me lembrei (p.Me) de verificar se todos os alunos tinham trazido artigos e na divisão dos grupos, alguns grupos tinham (p.Re) pouquíssimas reportagens. Talvez devêssemos ter compartilhado (p.Me) as reportagens .... Também não pude prceber (p.Me) se os alunos haviam lido (...) ou se apenas haviam recortado ... Se eu tivesse proposto (p.Me) um momento de compartilhar (...), poderia ter pedido ( $p$.Me)para que cada um contasse ... Isso me mostraria ( $p . M a)$ se eles haviam lido (p.Ex) ou não, e (...) se haviam entendido (p.Ex) o que leram.

Observação I

Interessante notar nas observações $\mathrm{F}$ e $\mathrm{J}$, o alto índice de processos comportamentais. Embora os observadores utilizem orações projetadas citadas, também recorrem aos processos comportamentais para relatarem as ações observadas, como por exemplo:

Professora toma (p.Co) a palavra e continua a explicação. (...)

Professora ignora (p.Co) a atitude de ambas; continua falando com a classe. (...)

Aluno vira-se (p.Co) para trás e da (p.Co) uma risada; outros riem (p.o) com ele; olham (p.Ma) para a observadora; param (p.Co) imediatamente.

Observação $F$

Num dado momento, professor grita (p.Co) com a classe e pede (p.Co) silencio. (...)

Professor passa (p.Ma) grande parte do tempo chamando (p.Co) a atenção dos alunos e ameaçando (p.Co) com pontuação negativa, se eles não ficarem (p.Co) quietos. (...)

Não presta (p.Co) atenção ao tipo de dificuldade ...

Professor faz (p.Co) de conta que não ouve e vai saindo da sala...

Observação $J$

Ao utilizar processos comportamentais para relatar as ações observadas, muitas vezes, o observador emite juízo de valor, como por exemplo, ao dizer "professora toma a palavra", ou "professor faz de conta que não ouve". Não há como certificar-se sobre a ação ocorrida nesse momento, com base nesse processo escolhido pelo observador. O professor pode tanto ter continuado a explicação após pausa longa na fala do aluno, quanto ter interrompido o aluno antes que este tivesse concluído seu pensamento, ou pode tanto ter ignorado o que o aluno disse quanto não ter realmente ouvido. $\mathrm{O}$ que temos nesses casos são as representações do observador apenas.

A observação D é, dentre as demais, a que apresenta menor índice de circunstâncias. Interessante notar que a ausência de elementos circunstan- 
ciais em relação aos processos, oferece-nos poucos detalhes sobre as ações observadas. Há um alto índice de processos materiais que apenas se complementam através da meta, como por exemplo:

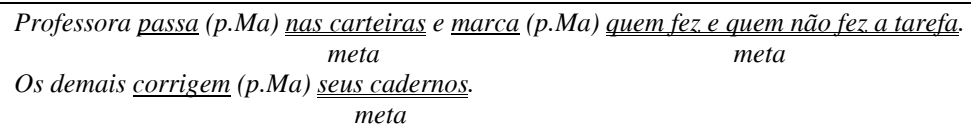

Observação D

Analisando a observação $\mathrm{H}$, podemos notar a presença de elementos lexicais de cunho avaliativo em discurso relatado, em escolhas feitas pelo observador. Tais escolhas podem "mascarar" as ações ocorridas durante a aula. Representam a avaliação do observador, expressando afeto, julgamento ou apreciação em relação ao observado.

Aula da professora transcorreu dentro da normalidade (...) alunos trabalharam bem, de maneira organizada, fazendo tudo o que a professora mandava. (...) Professora foi muito carinhosa com os alunos. Falava baixinho com as duplas. (...) Classe é muito organizada e os alunos são muito concentrados. (...) Ótima aula.

\subsubsection{Observador fala da ação de observar}

Analisando os relatos dos observadores sobre o que lhes foi perguntado a respeito de observação (O que é observar? O que observar? Como observar? Por que observar? Para que observar? A quem observar? Quando observar?), interessantes aspectos podem nos ajudar a entender como ocorre a atividade de observação. É possível notar, por exemplo, que regras regulam as ações dos sujeitos, como mostra o excerto a seguir:

Também o coordenador pedagógico nos observa, sempre que precisamos alguma ajuda ou alguma coisa não está bem em nossas aulas.

Observador A

Esse trecho pode nos indicar que o processo de observação ancora-se numa visão técnica, que considera um determinado padrão como o correto e as ações dos sujeitos buscam seguir esse padrão.

Um outro trecho destacado do relato do observador C confirma o papel das regras nas ações do sujeito observador: 
Sempre escolho um ponto chave para observar em minhas aulas, mas muitas vezes não sei explicar porque escolhi aquilo. Sigo as orientações da coordenação, que nos diz o quê devemos observar naquela semana.

Observador C

Ao dizer que não sabe explicar porque escolheu tal aspecto para observar, o observador revela não conhecer a necessidade de observar, e conseqüentemente, o porquê e o para quê.

Interessante notar, por exemplo, que muitos observadores vêem seu papel apenas como propiciando desenvolvimento ao participante observado, mas não se incluem no processo de desenvolvimento. Um exemplo disso é o que diz o observador D: ... observamos alguém quando alguma coisa não está bem e um processo de observação pode ajudar
aquela pessoa observada. (...) Depois de concluida a observação, oferecemos o que escrevemos ao
professor observado e ele pode, então, tomar conhecimento do que está acontecendo em sua aula.

Observador D

Observar (...) é um procedimento adotado por coordenadores pedagógicos e educacionais para verificar o que ocorre em sala de aula. (...) Minhas anotações sempre servem para propor ao professor estudar algum tópico relacionado ao aspecto pedagógico e isso tem contribuído para o aperfeicoamento dos professores ...

Observador E

No exemplo acima, podemos notar o papel da função interpessoal: para Halliday (1985), propor ao professor significa exigir que ele faça algo em troca. Se analisarmos ainda em função dos papéis atribuídos por Thompson \& Thetela (1995), quando o coordenador diz que pode propor ao professor estudar..., este seria o papel desempenhado pelo observador (exigir), que estaria projetando no professor observado a necessidade de aperfeiçoar-se em relação ao aspecto pedagógico.

Em um outro relato, o professor observador afirma o seguinte:

Nem sempre tenho oportunidade de conversar com o professor que me observa ou com aquele que eu observo. Apenas lemos o texto um do outro, mas isso não basta para mim. Sempre ficam algumas dúvidas sobre porque o observador vê determinadas coisas que eu não vejo.

Observador $F$

As ações no processo de observação tornam-se um dos artefatos culturais os quais o observador se utiliza. Assim também, seu relato de observação se transforma num artefato cultural cujo papel é mediar as relações entre observado e observador nas ações de análise da observação. Quando 
nos deparamos com o que diz esse professor observado, podemos concluir que o artefato cultural existe a partir das representações individuais dos sujeitos e como não é examinado por ambos os sujeitos em busca de explicações, não exerce seu papel de mediador entre sujeito e objeto da atividade (pois as ações de um dos sujeitos não estão no nível consciente ainda).

Analisando o relato de $\mathrm{G}$ a seguir,

Observar é um procedimento adotado por todos aqueles que desejam discutir sobre alguma coisa e querem certificar-se de como essa coisa acontece, sem emitir julgamentos antecipados. (...) Acredito que, ao observar, você pode preparar-se (...) Sempre que [eu] combino sobre uma seção de observação, [eu] procuro ter um momento de conversa (...) Esse procedimento tem nos ajudado...

Observador $G$

Podemos encontrar inúmeros indícios de que esse processo de observação pauta-se na reflexão crítica. Embora o observador utilize-se de projeção para referir-se à observação, não necessariamente incluindo-se na ação praticada (ao usar o dêitico todos), e logo a seguir usando você, a responsabilidade nesses casos é atribuída não à pessoa do observador, mas parece ser atribuída por ele a mais alguém. No entanto, finaliza o texto assumindo a responsabilidade do processo, ao dizer combino, procuro (implícito eu) e nos ajuda.

No relato de $\mathrm{H}$, fica clara a ausência de deliberação e avaliação, como definidas por Brookfield \& Preskill (1999).

Observamos colegas em sala de aula para dar um feedback a eles sobre o que eles fazem nas aulas (...) Também é importante incentivarmos o professor que observamos, pois não é fácil ser observada por alguém. Quando observo algum colega me preocupo em apresentar a ele um texto sobre minha observação que contenha coisas interessantes que ocorreram em sua aula. Acho que isso pode motivar o professor. (...) Somente conversamos com o professor depois da aula. Isso tem sido muito bom aqui na escola, porque as pessoas trocam experiências e aprendem umas com as outras.

Observador $H$

O professor observador preocupa-se em apresentar ao observado algo que o motive; não aparece no relato a preocupação com a situação observada apoiada em argumentos, nem tampouco a avaliação, que parece pautar-se em sentimentalismo apenas. Ao afirmar que somente conversamos (...) isso tem sido bom aqui na escola porque as pessoas trocam experiências e aprendem umas com as outras, também não há evidências explícitas de que as experiências são analisadas em busca de fundamentação teórica, o que nos leva a crer que a reflexão prática sustenta esse tipo de observação. 
Analisando o relato de I, é possível perceber como o papel desempenhado e a responsabilidade se fazem presentes. O relato é escrito predominantemente em $1^{\text {a }}$ pessoa do singular, o que demonstra que o observador desempenha um papel e se responsabiliza por ele, nomeando-se como o sujeito da atividade, tendo como referência ele próprio. O tempo verbal escolhido pelo observador em muitos momentos é o presente do indicativo, o que mostra uma ação em tempo real. O uso do presente contínuo, como por exemplo, "... minha maneira de trabalhar vem se modificando" indica um fazer em andamento, assim como os grupos verbais que recorrem ao verbo ter: "tem me ajudado, tenho procurado me reunir, tem proporcionado", e ainda: "estamos fazendo, procuro fazer".

Interessante nos relatos $\mathrm{E}$ e J, é que os textos são escritos predominantemente em $3^{\mathrm{a}}$ pessoa, como mostram os excertos a seguir:

Quem realiza a observação normalmente é o coordenador, e ele deve se preparar para isso, escolhendo o professor a ser observado e o motivo pelo qual esse professor precisa ser observado.

Observador E

É tarefa da coordenação observar algumas aulas desse professor e depois marcar uma reunião com ele para conversarmos sobre o que foi observado. (...)esse procedimento também deixa a coordenação em situação de desconforto, muitas vezes.

Observador $J$

Embora E e J sejam coordenadores pedagógicos, ambos se referem aos procedimentos de observação como se não fossem procedimentos praticados por eles. Isso pode significar um distanciamento daquele que fala. $\mathrm{O}$ observador parece distanciar-se da responsabilidade dessa ação, atribuindo-a a um outro sujeito, ou seja, projetando esse papel em um outro sujeito.

Predominantemente, nos relatos os observadores não fazem uso da forma nominal observador para referir-se àquele que observa. Referem-se ao observador utilizando eu, nós e a gente. A forma nominal observador aparece apenas 5 vezes nos relatos, enquanto que as formas pronominais eu e nós, e ainda a gente, referindo-se ao observador, somam 75 vezes. Essa é uma maneira de, discursivamente, o produtor do texto nomear-se observador.

Essa análise nos revela o sentido que o observador atribui ao papel dos sujeitos da atividade de observação: a ele próprio, predominantemente como o responsável pelo processo (quando se nomeia o observador utilizando nós, eu, a gente) e poucas vezes distanciando-se desse papel e conseqüentemente da responsabilidade (quando utiliza o observador). 
O sentido atribuído pelo observador ao seu papel é o de que embora muitas vezes ele não tenha ações conscientes sobre o ato de observar, isso é algo que exige que ele se prepare e representa uma tarefa que ele tem que cumprir porque faz parte de regras implícitas que permeiam as ações dos docentes nas escolas.

O sentido atribuído pelo observador ao papel do professor observado é, na maioria dos relatos, aquele imposto pelas regras da escola, relacionadas ainda à reflexão técnica e prática, que consideram observação como algo que oferece modelos a serem seguidos, ou que a consideram um processo de verificação de erros. Aparece também, em menor escala, o sentido de papel de observado como aquele sujeito que pode desencadear um processo de desenvolvimento, se sustentado por discussões e análises das ações ocorridas.

3.1.3. Sentidos que emergem do discurso do observador em relação aos elementos da atividade

Procurando caracterizar o objeto da atividade, investigo o que cada observador respondeu em relação às perguntas: Por que observar? e Para que observar?

Por que observar? Bem, porque é uma prática instituida na escola e isso tem orientado os estudos nas nossas reuniões pedagógicas.

Observador A

Acho que observar é importante porque a gente pode conversar com a pessoa observada tendo fatos concretos em mãos e não apenas coisas que estão em nossa mente, que pensamos ou imaginamos. As observações que faço servem sempre para estudo. (...)para melhorar o que fazemos em nossas aulas.

Observador $B$

Observamos colegas em sala de aula para dar um feedback a eles sobre o que eles fazem nas aulas. Observador $H$

O processo de observação é muito rico no sentido de que nos ajuda a compreender as nossas ações e a explicá-las. Também exige que estudemos, porque quando alguma coisa na observação não pode ser explicada, isso sinaliza que há algum ponto a ser mais discutido e estudado.

Observador I

Apenas em um dos relatos o observador aponta para o papel da observação como propiciadora de contextos de desenvolvimento das habilidades do pensamento critico. Como mostram os excertos acima, a preocupação 
dos observadores e o sentido atribuído por eles ao objeto da atividade de observação estão relacionados à melhoria das práticas de sala de aula e à identificação e resolução de problemas. Apenas o relato de I (excerto abaixo) nos oferece a possibilidade de pensar que o observador entende o processo de observação como um processo de desenvolvimento que necessita questionamentos, análise, preparação, revisão, e que tem como propósito o desenvolvimento não somente do participante observado, mas de todos os que indiretamente são influenciados pelas ações de observado e observador.

... Considero uma das maiores fontes de aprendizagem, pois desde que descobri como observar $e$
como fazer uso das observações sobre minhas aulas, minha maneira de trabalhar vem se modificando.
(...)Algumas vezes decidimos observar um aspecto da aula (da minha ou da dele), mas percebemos
que não pensamos da mesma forma sobre aquele ponto. Quando isso acontece, temos adiado a seção
de observação e sentado para conversar sobre o tal ponto. Isso tem me ajudado muito a estudar mais,
discutir com outra pessoa meu ponto de vista e tentar entender o ponto de vista do outro. (...)Também
exige que estudemos, porque quando alguma coisa na observação não pode ser explicada, isso
sinaliza que há algum ponto a ser mais discutido e estudado.

Esse trecho nos revela que o observador se nomeia sujeito da atividade, assumindo também o papel de observado, e que percebe o objeto da atividade em desenvolvimento, transformando-se durante o processo de observação.

Em relação aos artefatos de mediação, podemos olhar para os relatos considerando:

- o artefato de mediação "ação observada"

- o artefato de mediação "sessão de observação"

- o artefato de mediação "sessão pós observação"

Em relação ao artefato de mediação "ação observada", este se materializa no texto produzido pelos observadores sobre a aula assistida. O texto tem características descritivas e, como já vimos anteriormente, apresenta predominantemente processos verbais e materiais. Apenas no texto produzido pelo observador I, que observa a si mesmo através do vídeo referente à aula, aparecem referências explícitas sobre a influência da história e da cultura nas ações praticadas, como mostra o excerto seguinte: 
Não consegui isso nessa aula. Não consigo isso ainda. Somente eu faço perguntas para os alunos estabelecerem relações. Eles respondem pra mim e não para eles próprios no grupo. Isso é uma coisa que ainda não consigo fazer diferente porque sempre fizemos assim, na escola. Acho que me influencia muito aquilo que vivi na escola e o que meus professores sempre fizeram. Por mais que eu queira, ainda faço tudo igual.

Observador I

Os observadores, em seus relatos, sinalizam a compreensão de que esse tipo de artefato (ação observada / texto produzido a partir da ação) tem o papel de desenvolvimento apenas para o sujeito observado. Não há referências explícitas sobre como os observadores consideram esse artefato em seu próprio processo de desenvolvimento. Também não há referências explícitas dos observadores sobre o papel da cultura e da história na produção desses artefatos, ou seja, os observadores referem-se à aula observada como uma situação relacionada à prática do professor observado, apenas. Os exemplos a seguir evidenciam isso:

Costumamos conversar sobre o que foi observado e quando alguma coisa está dificil de entender, procuramos estudar sobre ela, para melhorar o que fazemos em nossas aulas.

Observador $B$

Se uma determinada atividade ${ }^{6}$ não dá certo, quando observamos como ela ocorreu sempre encontramos os pontos mais dificeis e podemos pensar em outras maneiras de realizá-la.

Observador $C$

Acho que seria muito interessante se todas as vezes que fazemos observações nos fosse oferecida a oportunidade de conversar sobre ela com o outro professor. Isso nos ajudaria a melhorar nossas aulas.

Observador $F$

Isso tem sido muito bom aqui na escola, porque as pessoas trocam experiências e aprendem umas com as outras.

Observador $H$

Nos excertos acima podemos notar a presença predominante do referente pronominal nós. Embora a pergunta inicial aos observadores tenha sido "O que é para você observar?", os relatos nos mostram que os observadores projetam para si um papel, mas compartilham essa responsabilidade

6. A palavra atividade, quando integrante do discurso dos participantes (portanto, nos registros coletados) não se refere ao conceito de atividade como discutido pela Teoria da Atividade e considerado neste trabalho. Nos registros coletados, "atividade" carrega o sentido e significado já cristalizado, das tarefas que um docente propõe e realiza com seus alunos. Mantenho, no entanto, a palavra escolhida pelo participante, a fim de não adulterar os dados. 
com um grupo de sujeitos. Também é importante observar nesses excertos, que os observadores utilizam processos mentais para referir-se à observação, o que pode indicar possibilidades, mas não ações concretas.

Em relação ao artefato "sessão pós-observação", encontramos indícios de que os observadores consideram sua importância, tanto para si quanto para o observado. No entanto, predominam referências ao artefato no nível das possibilidades. Os excertos a seguir mostram isso:

Gostaria sempre de poder combinar o que vou observar, porque acho que tanto eu quanto o outro professor nos sentiríamos mais seguros, tranqüilos sabendo qual é o ponto observado.

Observador A

Prefiro observar meus próprios vídeos porque nem sempre tenho tempo para escrever sobre o que observo e quando observo os meus próprios, não preciso escrever. Basta assisti-los.

Observador $C$

Nem sempre conseguimos conversar com o nosso par na observação, (...), então o mais comum é darmos a esse professor o texto que escrevemos sobre sua aula. Muitas vezes (...) não escrevemos nada.

Observador $H$

Em relação à comunidade, regras e divisão de trabalho, como já comentado anteriormente, os observadores explicitam o papel regulador desses elementos, e em nenhum momento referem-se a eles com possibilidades de negociação de significados. Esses elementos parecem não só definir o processo de observação, como também o de discussões sobre a observação. Ou seja: a atividade de observação está inserida nas ações da comunidade, mas não é analisada e entendida como elemento imprescindível ao desenvolvimento da comunidade.

Exemplos podem ser vistos nos trechos a seguir, quando encontramos a modulação como marca lingüística que caracteriza o discurso do observador em relação às ações de observação (identificada com sublinhado duplo), e a modalização como marca lingüística que caracteriza o discurso do observador em relação ao resultado da atividade, ainda que prático ou no nível das possibilidades (identificada com sublinhado simples):

Dependendo do ponto que deve ser observado, a gente precisa tomar muito cuidado porque deve anotar (...) é uma prática instituida na escola e isso tem orientado os estudos (...) Também o coordenador pedagógico nos observa, sempre que precisamos alguma ajuda (...) Muitas vezes isso nos ajuda a (...) melhorar nosso ensino. 
Eu acho uma pena, porque a gente sempre aprende nessas seções de observação.

Observador $B$

... devemos observar alguém quando alguma coisa não está bem

Observador D

É papel do coordenador saber o que acontece durante as aulas (...) Elas sempre servem para propor a professor estudar algum tópico relacionado ao aspecto pedagógico e isso parece contribuir para o aperfeiçoamento dos professores, de um modo geral.

Observador E

Esse procedimento tem [ação em direção ao Resultado] nos ajudado muito nas discussões pedagógicas em reuniões semanais e tem transformado [Resultado-nível prático] a prática de muitos professores, ajudando-os a entender porque fazem o que fazem.

Observador $G$

Meu coordenador tem proporcionado [ação em direção ao Resultado] ótimos momentos de discussão ao nosso grupo, a partir das sessões de observação (...) penso [Resultado - nível da possibilidade] que os que não estão envolvidos estão perdendo uma excelente oportunidade para aprender mais sobre o que fazemos: dar aula.

Observador I

\subsubsection{Sentidos que emergem das relações de simetria / assimetria entre os participantes}

Ainda que consideremos as relações entre as díades como mais, ou menos assimétricas, os registros das sessões de observação não revelaram a preponderância de elementos avaliativos em nenhum dos dois casos. Nas díades coordenador - professor, os processos verbais e materiais predominaram, assim como um alto índice de elementos circunstanciais. Já nos relatos dos coordenadores sobre sentido / significado de observar, a análise revelou que as razões dos coordenadores para a atividade de observar encontram-se ainda no interior do próprio objeto da atividade, relacionadas à necessidade de discutir a prática com os professores. A finalidade da observação, para eles, está em poder converter a sessão de observação em recurso para ser utilizado em reuniões com professores com o propósito de resolver situações inadequadas que ocorrem na escola, em sala de aula. O observado, para os coordenadores, predominantemente deve ser aquele que apresenta problemas em relação ao seu trabalho na escola. Isso pode indicar que, embora o coordenador não tenha feito uso de um discurso avaliativo em seu relato de observação, observar é um instrumento de avaliação das ações docentes, que instaura e confirma o poder do coordenador em relação ao professor. 
Nas díades professor - professor, nos registros das sessões de observação predominaram os processos verbais, seguidos dos materiais, com a presença de poucos elementos circunstanciais. Nos relatos dos professores observadores fica fortemente marcada a observação como imposição ou como instrumento de dominação utilizado na escola, mas ainda assim, todos os professores apontam o benefício dessa atividade, afirmando que ela contribui para a melhoria da prática e da troca de experiências. Um aspecto interessante que se destaca no que é apontado pelos professores é o fato de que quando o observador é o coordenador, o observado escolhido por ele é sempre alguém que apresenta problemas. Isso só vem a confirmar o que é dito pelos coordenadores.

Os professores que optaram pela auto-observação revelaram-se mais críticos. Apontaram, tanto na descrição de sua própria aula quanto no relato sobre observação, que essa atividade tem uma razão que extrapola a prática cotidiana, ou seja, a possibilidade de aprender a conscientizar-se a partir de suas próprias ações. Também esses professores afirmaram que a observação lhes permite entender, explicar sua prática e estudar sobre elas. Sugerem ainda que a atividade de observação só traria benefícios às escolas, mas que não são discutidas de maneira a esclarecer aos professores tais benefícios, mantendo-se, portanto, o estigma de instrumento avaliativo e de fiscalização do fazer docente nas escolas.

\section{Algumas conclusões}

Como proposto inicialmente, este artigo procurou discutir o processo de observação, focalizando o ponto de vista do observador. Apresentou aspectos teóricos que sustentam a observação, e ofereceu ao leitor subsídios para entender o que ocorre quando profissionais docentes realizam procedimentos de observação, quer a si próprios, quer a outros profissionais. Os registros considerados para análise mostraram que a observação, do ponto de vista do observador, parece não indicar desenvolvimento a ambos os sujeitos envolvidos no processo, mas apenas ao observado. Foi possível concluir também que a observação realiza-se num contexto de prática, não apresentando, por parte dos envolvidos, relação com o desenvolvimento das comunidades às quais os sujeitos - observado e observador pertencem. 
A presença marcante dos processos verbais e materiais nos textos produzidos pelos observadores nos oferece a possibilidade de pensar que a tarefa de observar cumpre um papel descritivo da ação docente. Os relatos dos observadores sobre a atividade de observar mostraram que a atividade não se encontra no nível de consciência plena para os envolvidos, o que significa que ainda não abstraem dela subsídios para seu desenvolvimento e das comunidades educativas.

A possibilidade de articular a lingüística sistêmico-funcional à teoria da atividade para sustentar este estudo nasceu principalmente do fato de que a teoria da atividade, por focalizar a historicidade como um dos principais fatores geradores de contradições para os indivíduos em relação à atividade que desenvolvem, e por entender que as práticas discursivas constituem-se artefatos de mediação por excelência para entender e romper com essas contradições, avançando na atividade, encontra necessidade de recorrer a um referencial lingüístico que explique os processos de conscientização dos seres humanos e como se apropriam do objeto da atividade, ultrapassando as barreiras historicamente constituídas no âmbito dessa atividade. Por outro lado, a lingüística sistêmico-funcional sustenta o fato de que as práticas discursivas e as estruturas sociais são interdependentes e se influenciam no decorrer de seu desenvolvimento. Sustenta ainda que todos os significados têm uma conexão direta tanto com o contexto social quanto com os elementos lexicogramaticais (Meurer 2004). Nesse sentido, toda e qualquer prática discursiva contém traços ideológicos calcados na sócio-cultura e nas relações históricas, dados a conhecer pelos sujeitos por meio das escolhas lexicogramaticais. Quando associamos, então, as práticas sociais, os papéis exercidos pelos sujeitos e as estruturas sociais das quais participam por meio das regras e da divisão do trabalho, estamos apontando para as conexões entre texto e contexto, e estamos, ao mesmo tempo, apontando para a atividade dos sujeitos e seus elementos constituídos historicamente e situados na história por meio das práticas sociais, incluindo a linguagem. $\mathrm{O}$ fato é que entender o contexto e mais especificamente as regras que orientam um sujeito em um contexto de ação numa atividade implica conhecer os significados e, portanto, a semântica aí presente.

Tais articulações levam-me a entender que teoria da atividade e lingüística sistêmico-funcional mantêm uma relação biunívoca tal que para entender as significações dadas pela historicidade e pelas contradições na atividade, posso apoiar-me nas metafunções da linguagem. Essas, por sua 
vez, só podem ser explicadas quando apoiadas na história dos sujeitos e na história de suas relações sociais e hierárquicas nos grupos aos quais pertencem. Ou seja, o importante, como afirma Meurer (2004), não é apontar como o sistema de significações se constitui em si, mas como essas significações exercem papel estruturador das práticas sociais para os indivíduos.

Neste trabalho pudemos perceber, ao discutir as análises, como a história da atividade de observação, que carrega a imagem positivista de "fiscalização", "verificação", exerce influência nas escolhas lexicais dos indivíduos. Pudemos perceber também como o elemento de superação das contradições situadas da atividade é a exploração, via linguagem, dos sentidos construídos pelos sujeitos. Esse fato, como alguns autores já vêm discutindo (dentre eles Hasan (1999/2000, p.2002) e Daniels (2004; 2006), confirma a interdependência entre teoria da atividade e lingüística sistêmico-funcional, porém, considero o desafio apenas lançado. Este artigo foi uma tentativa de mostrar essa interdependência e desencadear novos trabalhos que visem a explorar mais profundamente essa relação.

Como um outro desafio, considero ainda a possibilidade de que as escolas sistematizem procedimentos de observação, mas dêem a eles o lugar que merecem, no desenvolvimento dos profissionais, ou seja, sistematizem também os procedimentos de pós-observação, possibilitando aos profissionais discutirem sobre o que for observado, fundamentando-se teoricamente, e de maneira orientada. Espero que este artigo sirva como referência a profissionais coordenadores pedagógicos e orientadores de formação de professores, no sentido de organizarem tais espaços de reflexão junto àqueles que coordenam ou orientam.

Recebido em outubro de 2006 Aprovado em dezembro de 2008 E-mail: otilianinin@terra.com.br

\section{REFERÊNCIAS BibLIOGRÁFICAS}

Aranha, Maria Lúcia de Arruda; Martins, Maria Helena Pires. 1993. Filosofando: Introdução à filosofia. 2. ed. São Paulo: Moderna.

BeDny, Gregory Z. et al. 2000. Activity Theory: history, research and application. In: Theor. Issues in Ergon. SCI. 1:2, p.168-206. 
Brookfield, S. D.; Preskill, S. 1999. Discussion as a Way of Teaching: Tools and Techniques for Democratic Classrooms. San Francisco: Jossey-Bass Publishers.

Bueno, F. da Silveira. 2000. Dicionário escolar. São Paulo: Ediouro.

Celani, M. A. A.; Magalhães, M. C. C. 2002. Representações de professores de inglês como língua estrangeira sobre identidades profissionais: uma proposta de reconstrução. In: MoITA Lopes, L. P.; BAstos, L. C. (Orgs.) Identidades: recortes multi interdisciplinares. Campinas: Mercado de Letras. Clot, Yves. 2006. Vygotsky: para além da Psicología Cognitiva. Pro-Posições. $17: 2(50)$.

Cole, M.; Engeström, Y. 1993. A cultural-historical approach to distributes cognition. In: Salomon, G. (Ed.) Distributes Cognition: Psychological and Educational Considerations. Cambridge: Cambridge University Press.

Dalacorte, Maria Cristina Faria. 2003. A mudança de turnos na sala de aula de língua inglesa. Linguagem E Ensino. 6:1(35-56). Universidade Federal de Goiás.

Daniels, Harry. 2004. Activity, theory, discourse and Bernstein. In: Daniels, H.; Edwards, A. (Eds.) Educational Review. 56:2, p.121-132.

Ferreira, Aurélio B. H. 1993. Minidicionário da língua portuguesa. 3. ed. Rio de Janeiro: Nova Fronteira.

EgGINs, S. 1994. An Introduction to Systemic Functional Linguistics. London: Continuum Printer Publishers.

Engeström, Y. 1987. Learning by Expanding: An Activity Theoretical Approach to Developmental Research. Helsinki: Orienta-Konsultit Oy.

. 1999a. Learning by Expanding: Ten Years After. Introduction to the German edition of Learning by Expanding, published under the title Lernen durch Expansion. Marburg: BdWi-Verlag.

. 1999b. Activity theory and individual and social transformation. In: Engeström, Y. et al. Perspectives on Activity Theory and Context. Cambridge: Cambridge, University Press.

.2001. Expansive learning at work: Toward an activity theoretical reconceptualization. Journal of Education and Work. 14:1.

Giroux, Henry. Cruzando as Fronteiras do discurso Educacional. Trad. Magda França Lopes. Porto Alegre: artmed, 1999.

. Entrevista com Henry Giroux. In: Torres, C.A. et al. Educação, Poder e Biografia Pessoal. Diálogos com educadores críticos. Porto Alegre: Artes Médicas, 2000. 
Halliday, M. A. K. 1985. An Introduction to Functional Grammar. London: Edward Arnold.

Halliday, M. A. K.; Hasan, R. 1989. Language, Context, and Text: Aspects of Language in a Social-Semiotic Perspective. 2. ed. Oxford: Oxford University Press.

HaSAn, R. 1999. Society, Language and the mind: The meta-dialogism of Basil Bernstein's Theory. In: Christie, Frances. (ed.) Pedagogy and the Shaping of Consciousness - Linguistic and Social Processes. Continuum. London and New York: Cassel. 2002. Semiotic mediation, language and society: Three exotripic theories - Vygotsky, Halliday and Bernstein. Paper apresentado no $2^{\circ}$ Simpósio Internacional Basil Bernstein. Universidade de Cape, Town. 17 a 19 de julho de 2002.

Hernández, Fernando. 1998. Transgressão e mudança na educação: os projetos de trabalho. Trad. Jussara H.Rodrigues. Porto Alegre: Artmed.

Hirano, Eliana K. 2003. Dificuldade de aprendizagem? A reconstrução de identidade de um aprendiz de língua estrangeira na relação com o outro. Dissertação de Mestrado em Lingüística Aplicada e Estudos da Linguagem. Pontifícia Universidade Católica de São Paulo.

Kemmis, S. 1987. Critical reflection. In: Wideen, M. F.; Andrews, I. (eds) Staff Development for School Improvement. Philadelphia: The Falmer Press. Leontiev, A. N. 1978. Activity, Consciousness and Personality. http:// lchc.ucsd.edu/ MCA/Paper/leontev/. Consultado em 20 dez. 2005.

Liberali, Fernanda Coelho. 1994. O papel do coordenador no processo reflexivo do professor. Dissertação de Mestrado em Lingüística Aplicada ao Ensino de Línguas. Pontifícia Universidade Católica de São Paulo. . 1998. O diário como ferramenta para a reflexão crítica. Tese de Doutorado em Lingüística Aplicada ao Ensino de Línguas. Pontifícia Universidade Católica de São Paulo.

Lucioli, Rosiméri. 2003. As perguntas como mediadores na construção de conhecimentos. Dissertação de Mestrado em Lingüística Aplicada e Estudos da Linguagem. Pontifícia Universidade Católica de São Paulo. LuRia, A. R. 1986. O cérebro humano e a atividade consciente. In: VyGotsky, L. S.; LuRIA, A. R.; LeONTIEv, A. N. Linguagem, desenvolvimento e aprendizagem. São Paulo: Ícone, 1998.

Luria, A. R. 1986. Pensamento e Linguagem. As últimas conferências de Luria. Porto Alegre: Artmed, 2001. 
Magalhães, M.Cecília C. 2000. Narrative and argument in teacher and researcher interactions on classroom discourse: Different ways of organizing salient and problematic action. In: HedegaARD, M. (Eds.), School Learning, Teaching Activity and Cognition. Aarhus University Press. . 2002. O professor de línguas como pesquisador de sua ação: A pesquisa colaborativa. In: Gimenez, Telma (Org.) Trajetórias na Formação de Professores de Linguas. Londrina: Editora UEL.

Mc Laren, Peter. 1977. A vida nas escolas. Uma introdução à pedagogia crítica nos fundamentos da educação. 2. ed. Trad. Lucia P.Zimmer et al. Porto Alegre: Artemed.

Mc Laren, Peter; Giroux, Henry. 1997. Escrevendo das margens: Geografias de identidade, pedagogia e poder. In: Mc Laren, Peter (Org). Multiculturalismo revolucionário. Pedagogia do dissenso para o novo milênio. Trad. Márcia Moraes; Roberto C.Costa. Porto Alegre: Artmed.

Melo, Tatiana Machado Miliante de. 2002. A conjugação teoria/prática na sala de aula comunicativa de ILE Uma experiência de pesquisa-ação. Linguagem E Ensino. 5:1(149-169). Universidade Federal do Rio de Janeiro.

Meurer, José Luiz. 2004. Ampliando a noção de contexto na Lingüística Sistêmico-Funcional e na Análise Crítica do Discurso. Revista Linguagem em (Dis)curso. Vol. 4, Número Especial, p.133-157.

Ninin, M.Otilia Guimarães. 2002. Instrumentos investigativos na formação contínua: Por uma prática dialógica entre professor e coordenador. Dissertação de Mestrado em Lingüística Aplicada e Estudos da Linguagem. Pontifícia Universidade Católica de São Paulo.

Santos, Eliane Andreoli dos. 2002. O computador na aula de inglês no Ensino Fundamental: Os interesses dos alunos e a elaboração de tarefa baseada em gênero. Dissertação de Mestrado em Lingüística Aplicada e Estudos da Linguagem. Pontifícia Universidade Católica de São Paulo.

Schaffer, H. Rudolph. 1992. Episódios de envolvimento conjunto como contexto para o desenvolvimento. In: Daniels, Herry. Uma introdução a Vygotsky. Trad. Marcos Bagno. São Paulo: Loyola.

Schneuwly, B. 1994. Contradiction and development: Vygotsky and Paedology. European Journal of Psychology of Education, n. 9, p.281-291. Swaffar, Janet K. et al. 1982. Teacher Classroom Practices: Redefining Method as Task Hierarchy. Modern Language Journal. 66:1, p. 24-33.

SzUNDY, Paula. 2005. A construção do conhecimento no jogo e sobre o jogo ensinoaprendizagem de LE e formação reflexiva. Tese de Doutorado em Lingüística 
Aplicada e Estudos da Linguagem. Pontifícia Universidade Católica de São Paulo.

Thompson, G.; Thetela, P. 1995. The Sound of One Hand Clapping: The Management of Interaction in Written Discourse. Text 15 (1), p. 103-127.

Van Manen, M. 1977. Linking Ways of Knowing with Ways of Being Practical. Curriculum Inquiry. 6:3.

Vygotsky, L. S. 2000. Pensamento e Linguagem. 2. ed. Trad. Jefferson Luiz Camargo. São Paulo: Martins Fontes,

Zabala, Antoni. 1995. A prática educativa: Como ensinar. Porto Alegre: Artes Médicas.

Zygmantas, Janete. 2004. O ensino-aprendizagem de leitura em LE: Foco na (re) construção dos dignificados. Dissertação de Mestrado em Lingüística Aplicada e Estudos da Linguagem. Pontifícia Universidade Católica de São Paulo.

Celani, M. Antonieta A.; Magalhães, M. Cecilia C. 2001. Representações de professores de Inglês como Língua Estrangeira sobre suas identidades profissionais: Uma proposta de reconstrução. Simpósio Nacional: Discurso, Identidade e Sociedade. PUC-RJ. 17, 18 e 19 maio 2001.

Magalhães, M. Cecilia C. 1992. Teacher \& researcher dialogical interactions: Learning and promoting literacy development. Proceedings for the $1^{\text {st }}$ Conference for Socio-Cultural Research. IV. Madrid: Infancia Y Aprendizaje. MAgAlHÃEs, M. Cecilia C. 1996. A pragmática como negociação de sentidos. Cadernos de Estudos Lingüísticos, n. 30, p. 57-70. Campinas:Unicamp. Richards, Jack C.; LockHart, Charles. 1994. Reflective Teaching in Second Language Classrooms. Cambridge: Cambridge University Press. 


\section{Anexo 1}

OBSERVAÇÃO A - professor (observador A) observa colega em sala de aula; alunos de $2^{\underline{a}}$ série do Ensino Médio; aula de Geografia. Assunto combinado para observação: como o professor questiona os alunos.

OBSERVAÇÃO B - professor (observador B) observa colega em sala de aula; alunos de $2^{\underline{a}}$ série do Ensino Fundamental; aula de Língua Portuguesa e Ciências. Assunto combinado para observação: como o professor questiona os alunos.

OBSERVAÇÃO C - professor (observador C) observa um vídeo gravado de sua própria aula; alunos de 6 ${ }^{\underline{a}}$ série do Ensino Fundamental; aula de Matemática. Assunto escolhido pela professora para observar: como ela questiona os alunos.

OBSERVAÇÃO D - professor (observador D) observa colega em sala de aula; alunos de $5^{\underline{a}}$ série do Ensino Fundamental; aula de Português. Assunto combinado para observação: como o professor corrige tarefas.

OBSERVAÇÃO E - coordenador (observador E) observa professor em sala de aula; alunos de $1^{\underline{a}}$ série do Ensino Médio; aula de Matemática. Assunto combinado para observação: nada foi combinado.

OBSERVAÇÃO F - professor (observador F) observa colega em sala de aula; alunos de 6 ${ }^{a}$ série do Ensino Fundamental; aula de História. Assunto combinado para observação: como professora fala com os alunos.

OBSERVAÇÃO G - coordenador (observador G)observa professor em sala de aula; alunos de 7a série do Ensino Fundamental; aula de Ciências. Assunto combinado para observação: como professora trabalha com os conhecimentos prévios.

OBSERVAÇÃO H - professor (observador H) observa colega em sala de aula; alunos de $3^{\underline{a}}$ série do Ensino Fundamental; aula de Português. Assunto combinado para observação: nada foi combinado.

OBSERVAÇÃO I - professor (observador I) observa um vídeo gravado de sua própria aula; alunos de 8a série do Ensino Fundamental; aula de Geografia. Assunto escolhido pela professora para observar: como ela orienta um trabalho em sala de aula.

OBSERVAÇÃO J - coordenador (observador J) observa professor em sala de aula; alunos de 5a série do Ensino Fundamental; aula de Geografia. Assunto combinado para observação: nada foi combinado. 